\title{
Water Sorption Evolution Enabled by Reticular Construction of Zirconium Metal-Organic Frameworks Based on Unique
}

\section{[2.2]Paracyclophane Scaffold}

Wei Gong, ${ }^{\dagger} \pitchfork$ Haomiao Xie, ${ }^{\ddagger}$ Karam B. Idrees, ${ }^{\ddagger}$ Florencia A. Son, ${ }^{\ddagger}$ Zhijie Chen, ${ }^{\ddagger}$ Fanrui Sha,${ }^{\ddagger}$ Yan Liu,${ }^{\dagger}$ Yong Cui ${ }^{*}{ }^{\dagger}$ and Omar K. Farha* ${ }^{*}, \S$

†School of Chemistry and Chemical Engineering, Frontiers Science Center for Transformative Molecules and State Key Laboratory of Metal Matrix Composites, Shanghai Jiao Tong University, Shanghai 200240, P. R. China

Department of Chemistry and International Institute for Nanotechnology (IIN), Northwestern University, Evanston, Illinois 60208, United States

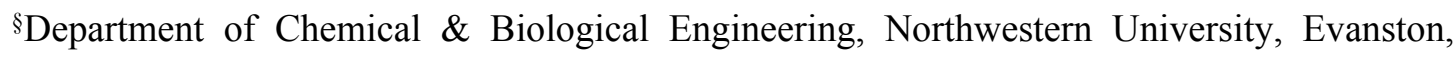
Illinois 60208, United States

Email: yongcui@sjtu.edu.cn; o-farha@northwestern.edu

\section{Table of Content}

1. Materials and general procedures

2. Synthesis of organic linkers

3. Crystal data and structure refinements of NU-700 and NU-405

4. Crystal data and structure refinement of NU-1800, NU-913, and NU-602

5. X-ray crystallographic structures of reported Zr-MOFs

6. PXRD patterns of NU-700, NU-405, and NU-1800

7. $\mathrm{N}_{2}$ sorption isotherms of NU-700, NU-405, and NU-1800

8. Water sorption isotherms of NU-700, NU-405, and NU-1800

9. TGA curves of reported $\mathrm{Zr}-\mathrm{MOF}$

10. NMR spectra of digested NU-913-HAc and NU-913-TFA

11. SEM images of reported Zr-MOFs

12. Comparison of water sorption performances with other porous materials 


\section{Materials and general procedures}

All the chemicals are commercially available and were used without further purification. Thermogravimetric analyses (TGA) were performed on a TGA/DCS 1 system (Mettler-Toledo, Columbus, OH) with STARe software. Samples were heated from 25 to $800{ }^{\circ} \mathrm{C}$ at a rate of $5{ }^{\circ} \mathrm{C} / \mathrm{min}$ under $\mathrm{N}_{2}$ with flow rate $20 \mathrm{~mL} / \mathrm{min}$. Powder X-ray diffraction (PXRD) data were collected on a STOE-STADI P powder diffractometer operating at $40 \mathrm{kV}$ voltage and $40 \mathrm{~mA}$ current with $\mathrm{Cu}-\mathrm{K} \alpha 1$ $\mathrm{X}$-ray radiation $(\lambda=0.154056 \mathrm{~nm})$ in transmission geometry. The calculated PXRD patterns were produced using the Mercury software and single crystal reflection data. ${ }^{1} \mathrm{H}$ NMR and ${ }^{19} \mathrm{~F}$ NMR experiments were carried out on a Bruker Avance III $500 \mathrm{MHz}$ system. $\mathrm{N}_{2}$ sorption isotherms were measured using a Micrometritics ASAP 2420 surface area analyzer at $77 \mathrm{~K}$. Before the isotherm measurement, NU-700 was exchanged with acetone 3 times ( $6 \mathrm{~h}$ for each exchange) and then degassed on ASAP 2420 for $10 \mathrm{~h}$ at $25^{\circ} \mathrm{C}$; NU-405 and NU-1800 were activated using supercritical $\mathrm{CO}_{2}$ and placed under dynamic vacuum on the ASAP 2420 for $2 \mathrm{~h}$ at $25^{\circ} \mathrm{C}$; NU-913 and NU-602 were exchanged with acetone 3 times ( $6 \mathrm{~h}$ for each exchange) and then degassed on ASAP 2420 for $10 \mathrm{~h}$ at $120^{\circ} \mathrm{C}$. SEM images were acquired using a Hitachi SU8030 scanning electron microscope. Prior to imaging, the sample was coated with OsO4 $(\sim 9 \mathrm{~nm})$ in a Denton Desk III TSC Sputter Coater. Water isotherms were measured on a Micromeritics 3Flex, and the water uptake in $\mathrm{g} \mathrm{g}^{-1}$ units is calculated as [(adsorbed amount of water)/ (amount of adsorbent)]. Prior to the water adsorption measurements, water (analyte) was flash frozen under liquid nitrogen and then evacuated under dynamic vacuum at least 3 times to remove any gases in the water reservoir. The temperature was controlled with a Micromeritics ISO Controller. For the ${ }^{19} \mathrm{~F}$ spectra, NU-913-TFA was first digested with small amount of $\mathrm{D}_{2} \mathrm{SO}_{4}-d_{6}$ solvent and then dissolved in $0.5 \mathrm{~mL}$ DMSO- $d_{6}$ solvent. 1-bromo-3,5- bis(trifluoromethyl)benzene was added and used as an internal standard to calculate the exact amount of the TFA on the node.

Single crystal X-ray crystallography. All the single-crystal XRD data presented in this paper were collected at $100 \mathrm{~K}$ under a nitrogen cryostream using a Bruker KAPPA APEX II (Bruker, Billerica, MA) equipped with an APEX2 CCD detector, Cryostream 80-400K (Oxford Cryosystems, Oxford, United Kingdom), and $\mathrm{CuK} \alpha(\lambda=1.54178 \AA) \mathrm{I} \mu \mathrm{S}$ microfocus source with MX Optics and a Kappa geometry goniometer. For NU-602, although we collected over six sets of crystal data, the diffraction quality was too low for structure determination. Therefore, we prepared a Hf version to obtain better diffraction data. Crystal morphology and PXRD both validated that they are isostructural. The structures were determined by intrinsic phasing (SHELXT 2014/5) (Acta Crystallogr $A$ 2015, 71, 3) and refined by full-matrix least squares refinement on F2 (SHELXL2014/7) (Acta Crystallographica Section C 2015, 71, 3.) using the Olex2 (J. Appl. Crystallogr. 2009, $42,339)$ software package. All hydrogen atom positions were added to their mother carbon atoms by geometry and refined by a riding model. DFIX, RIGU, SADI, ISOR and SIMU restrains were used to obtain reasonable parameters. The solvent molecules and ions were highly disordered and attempts to locate and refine the solvent peaks were unsuccessful. Contributions to scattering due to these solvent molecules were removed using the SQUEEZE routine of Olex2. The contents of the solvent region are not represented in the unit cell contents in the final crystal data. Crystal data and details of the data collection are given in Tables S1-S2 . CCDC 2121001 (NU-700), 2121003 (NU405), 2121006 (NU-1800), 2121005 (NU-913) and 2121004 (NU-602) contain the supplementary crystallographic data for this paper. The data can be obtained free of charge from The Cambridge Crystallographic Data Centre via www.ccdc.cam.ac.uk/data_request/cif. 


\section{Synthesis of organic linkers}

\subsection{Synthesis of the linker $\mathrm{L} 1$}

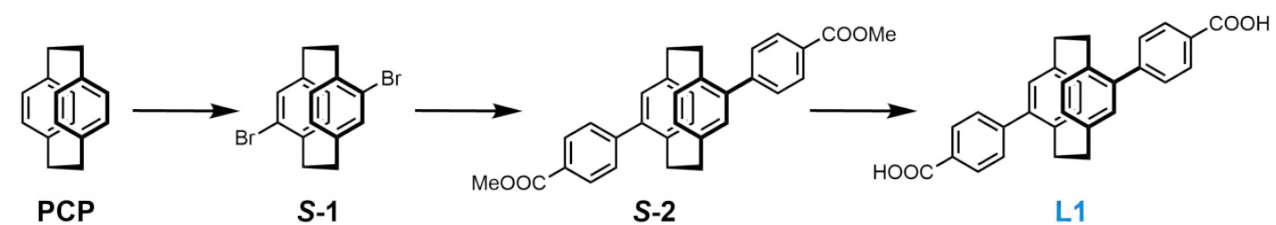

$S$-1: To a solution of [2.2]paracyclophane (PCP) $(25.0 \mathrm{~g}, 0.12 \mathrm{~mol})$ in $\mathrm{CCl}_{4}(500 \mathrm{~mL})$, liquid bromine $\left(40 \mathrm{~mL}, 0.8 \mathrm{~mol}\right.$ ) was added at room temperature, and the mixture was heated at $60{ }^{\circ} \mathrm{C}$ for $6 \mathrm{~h}$. A precipitate formed during the course of reaction. After the reaction was completed, as monitored by TLC, the mixture was cooled in an ice bath and an aqueous solution of sodium bisulfite was added with continuous stirring. The precipitate was removed by filtration, washed with water thoroughly, and then washed with EtOH. Pseudo-para-dibromo[2.2]paracyclophane was obtained as an offwhite powder with $35 \%$ yield.

$S$-2: $S$-1 (3.64 g, $10 \mathrm{mmol}), 4$-methoxycarbonylphenylboronic acid ( $6.3 \mathrm{~g}, 35 \mathrm{mmol}), \mathrm{K}_{2} \mathrm{CO}_{3}(8.3 \mathrm{~g}$, $60 \mathrm{mmol})$, and $\mathrm{Pd}\left(\mathrm{PPh}_{3}\right)_{4}(0.6 \mathrm{~g}, 0.5 \mathrm{mmol})$ were added into a $250 \mathrm{~mL}$ flame-dried round-bottom flask. The flask was evacuated under vacuum and refilled with $\mathrm{N}_{2}$ three times. Degassed 1,2dimethoxyethane $(120 \mathrm{~mL})$ and water $(40 \mathrm{~mL})$ were added, and the mixture was heated at $90{ }^{\circ} \mathrm{C}$ overnight. Then, the reaction mixture was cooled to room temperature and concentrated. The residue was extracted with DCM. The organic layer was collected, dried over anhydrous $\mathrm{Na}_{2} \mathrm{SO}_{4}$, and concentrated under reduced pressure. The crude product was purified by column chromatography on silica gel (10:1, PE-EA, v/v) to yield $S-2$ as a white solid (3.35 g, 70\%).

L1: A solution of $S-2(3.35 \mathrm{~g}, 7 \mathrm{mmol}), \mathrm{NaOH}(2.8 \mathrm{~g}, 70 \mathrm{mmol})$, THF $(30 \mathrm{~mL})$, and $\mathrm{H}_{2} \mathrm{O}(60 \mathrm{~mL})$ was heated at $80^{\circ} \mathrm{C}$ for $12 \mathrm{~h}$. After cooling to room temperature, the organic solvents were removed in vacuo and the water phase was acidified to $\mathrm{pH}=5$ with $2 \mathrm{M} \mathrm{HCl}$. The precipitate was filtrated and dried under vacuum at $60{ }^{\circ} \mathrm{C}$ overnight to give $\mathrm{L} 1$ as a white solid $(2.88 \mathrm{~g}, 92 \%) .{ }^{1} \mathrm{H}$ NMR (500 MHz, DMSO) $\delta 12.96(\mathrm{~s}, 2 \mathrm{H}), 8.09(\mathrm{~d}, J=8.1 \mathrm{~Hz}, 4 \mathrm{H}), 7.65(\mathrm{dd}, J=35.8,8.3 \mathrm{~Hz}, 4 \mathrm{H}), 6.85(\mathrm{~d}, J$ $=7.7 \mathrm{~Hz}, 2 \mathrm{H}), 6.76(\mathrm{~s}, 2 \mathrm{H}), 6.50(\mathrm{~d}, J=7.1 \mathrm{~Hz}, 2 \mathrm{H}), 4.03(\mathrm{dd}, J=14.2,7.1 \mathrm{~Hz}, 2 \mathrm{H}), 3.15-3.02(\mathrm{~m}$, 2H), 2.93-2.84 (m, 2H), 2.68-2.59 (m, 2H). ${ }^{13} \mathrm{C}$ NMR (126 MHz, DMSO) $\delta 137.25,135.55,132.52$, $132.00,131.92,130.47,130.16,129.28,129.19,127.54,34.52,33.64$. Due to poor solubility of L1 in DMSO, the signals of ${ }^{13} \mathrm{C}$ NMR are relatively weak.

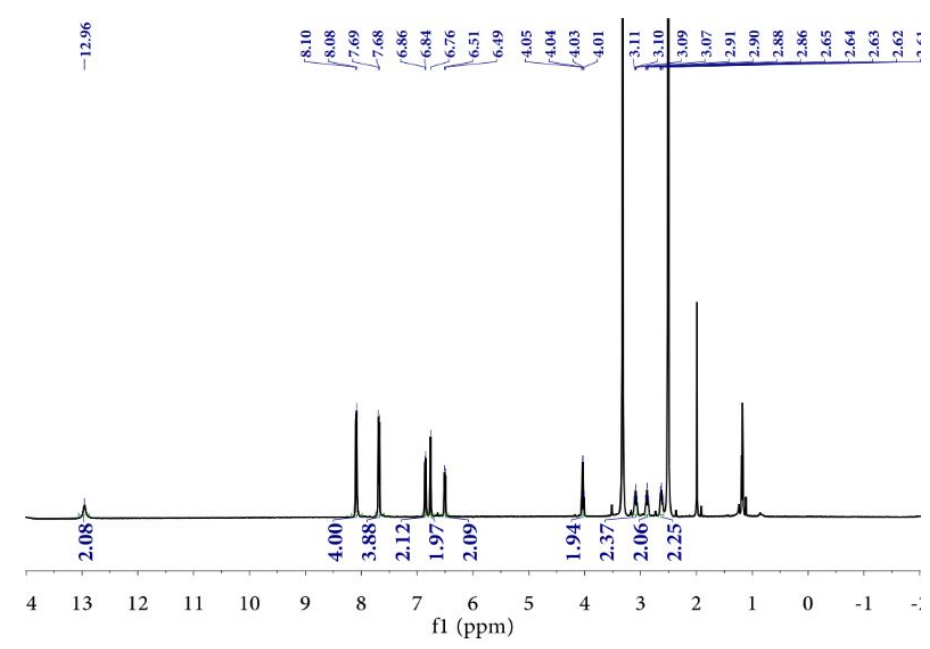




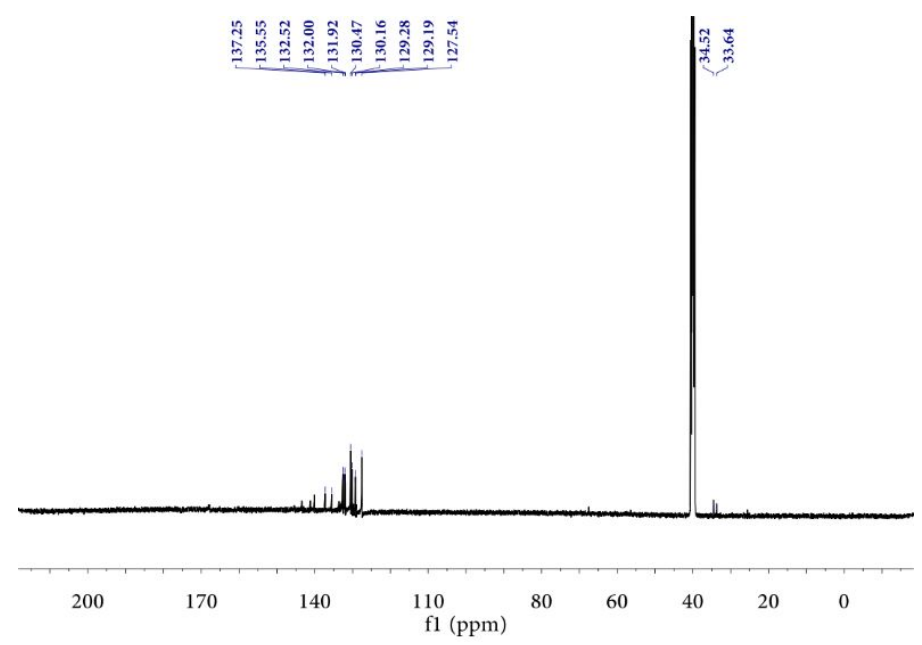

\subsection{Synthesis of the linkers $L 2$ and $L 3$}

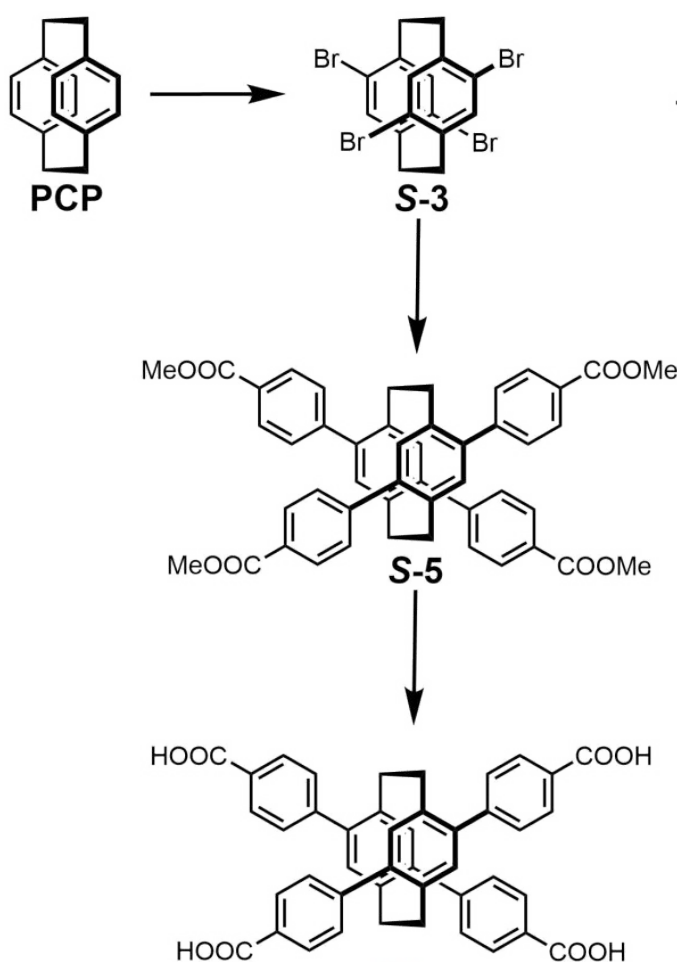

L2

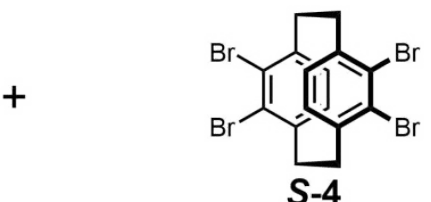

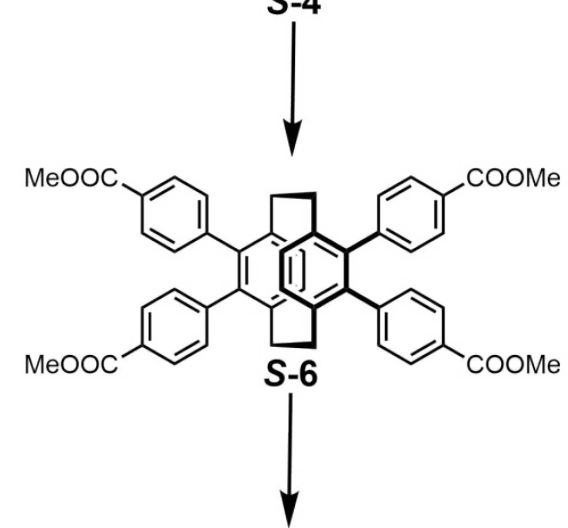<smiles>O=C(O)c1ccc(-c2c3c(c(-c4ccc(C(=O)O)c(-c5ccc(C(=O)O)cc5)c4-c4ccc(C(=O)O)cc4)c4c2CCC4)CCC3)cc1</smiles>

L3

$S$-3 and $S$-4: $10.0 \mathrm{~g}$ (48 mmol) of [2.2]paracyclophane (PCP) was slowly added in small aliquots to a mixture of $30 \mathrm{ml}(589 \mathrm{mmol})$ of bromine and $0.15 \mathrm{~g}(0.6 \mathrm{mmol})$ of iodine. The solution was kept in the dark (caution: vigorous evolution of hydrogen bromide!) and stirred for $3 \mathrm{~d}$ at room temperature in a flask wrapped with aluminum foil to exclude daylight. The reaction mixture was then decomposed by addition of $300 \mathrm{ml}$ of $20 \%$ aqueous sodium hydroxide. The precipitate was collected by filtration, washed with $3 \times 50 \mathrm{ml}$ of hot ethanol, and dried in vacuo, yielding $20 \mathrm{~g}$ as a mixture of $S-3$ and $S-4$ in equal amounts. Then, the isomers were extracted with $4 \times 80 \mathrm{ml}$ of dichloromethane to yield pure $S-4$ of about $9 \mathrm{~g}$. The filtrate was removed in vacuo and washed with small amount of dichloromethane for several times and concentrated under reduced pressure to give pure $S-3$ of about $7 \mathrm{~g}$.

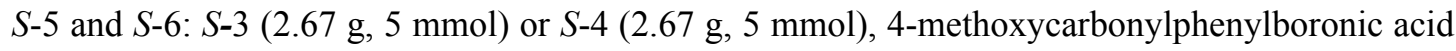
$(5.4 \mathrm{~g}, 30 \mathrm{mmol}), \mathrm{K}_{3} \mathrm{PO}_{4}(10.6 \mathrm{~g}, 50 \mathrm{mmol})$, and $\mathrm{Pd}\left(\mathrm{PPh}_{3}\right)_{4}(0.6 \mathrm{~g}, 0.5 \mathrm{mmol})$ were added into a 250 
$\mathrm{mL}$ flame-dried round-bottom flask. The flask was evacuated under vacuum and refilled with $\mathrm{N}_{2}$ three times. Degassed 1,2-dimethoxyethane $(120 \mathrm{~mL})$ and water $(40 \mathrm{~mL})$ were added, and the mixture was heated at $90^{\circ} \mathrm{C}$ overnight. Then, the reaction mixture was cooled to room temperature and concentrated. The residue was extracted with DCM. The organic layer was collected, dried over anhydrous $\mathrm{Na}_{2} \mathrm{SO}_{4}$, and concentrated under reduced pressure. The crude product was purified by column chromatography on silica gel (10:1 to 5:1, PE-EA, v/v) to yield $S-5(2.8 \mathrm{~g}, 74 \%)$ or $S-6(2.4$ $\mathrm{g}, 63 \%)$ as a white solid.

L2: A solution of $S-5$ (2.8 g, $3.7 \mathrm{mmol}), \mathrm{NaOH}(5.9 \mathrm{~g}, 148 \mathrm{mmol})$, THF (30 mL), and $\mathrm{H}_{2} \mathrm{O}(60 \mathrm{~mL})$ was heated at $80^{\circ} \mathrm{C}$ for $12 \mathrm{~h}$. After cooling to room temperature, the organic solvents were removed in vacuo and the water phase was acidified to $\mathrm{pH}=5$ with $2 \mathrm{M} \mathrm{HCl}$. The precipitate was filtrated and dried under vacuum at $60^{\circ} \mathrm{C}$ overnight to give $\mathrm{L} 2$ as a white solid $(2.45 \mathrm{~g}, 94 \%) .{ }^{1} \mathrm{H}$ NMR (500 MHz, DMSO) $\delta 12.99$ (s, 4H), 7.99 (d, $J=8.4 \mathrm{~Hz}, 8 \mathrm{H}), 7.49$ (d, $J=8.3 \mathrm{~Hz}, 8 \mathrm{H}), 6.87$ (s, 4H), 3.45 $(\mathrm{dd}, J=11.6,5.4 \mathrm{~Hz}, 4 \mathrm{H}), 2.88(\mathrm{dd}, J=11.8,5.5 \mathrm{~Hz}, 4 \mathrm{H}) .{ }^{13} \mathrm{C}$ NMR $(126 \mathrm{MHz}, \mathrm{DMSO}) \delta 167.60$, $144.34,139.53,137.75,132.75,130.19,129.75,129.25,33.22,21.50$.
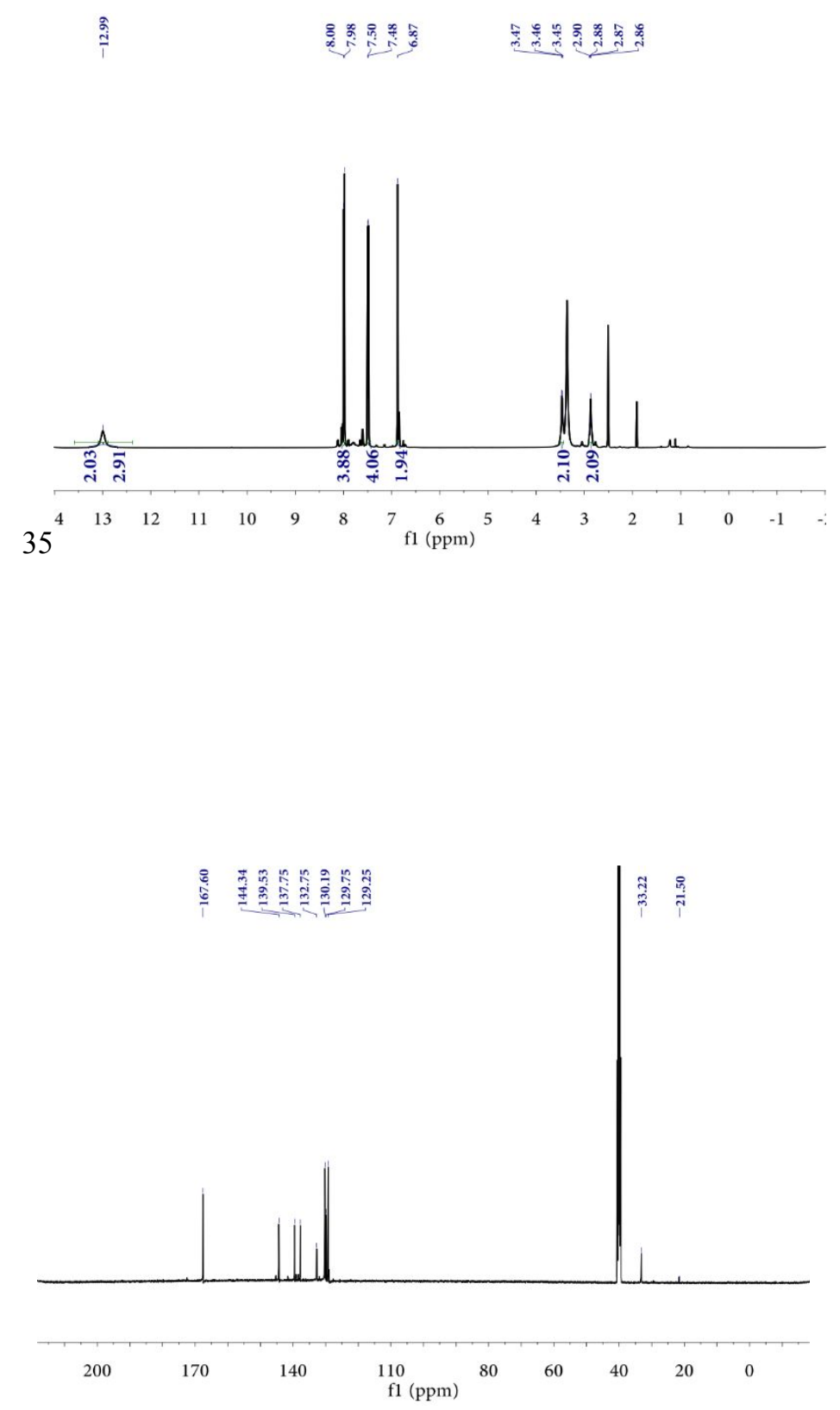
L3 was synthesized using the same procedure with L2. ${ }^{1} \mathrm{H}$ NMR (500 MHz, DMSO) $\delta 12.90$ (s, $4 \mathrm{H}), 8.07-7.51(\mathrm{~m}, 12 \mathrm{H}), 6.85(\mathrm{~s}, 8 \mathrm{H}), 3.06(\mathrm{dd}, J=13.1,10.2 \mathrm{~Hz}, 4 \mathrm{H}), 2.84-2.70(\mathrm{~m}, 4 \mathrm{H}) .{ }^{13} \mathrm{C}$ NMR (126 MHz, DMSO) $\delta$ 167.67, 144.46, 139.06, 138.35, 131.91, 129.19, 129.05, 128.99, 33.31 .
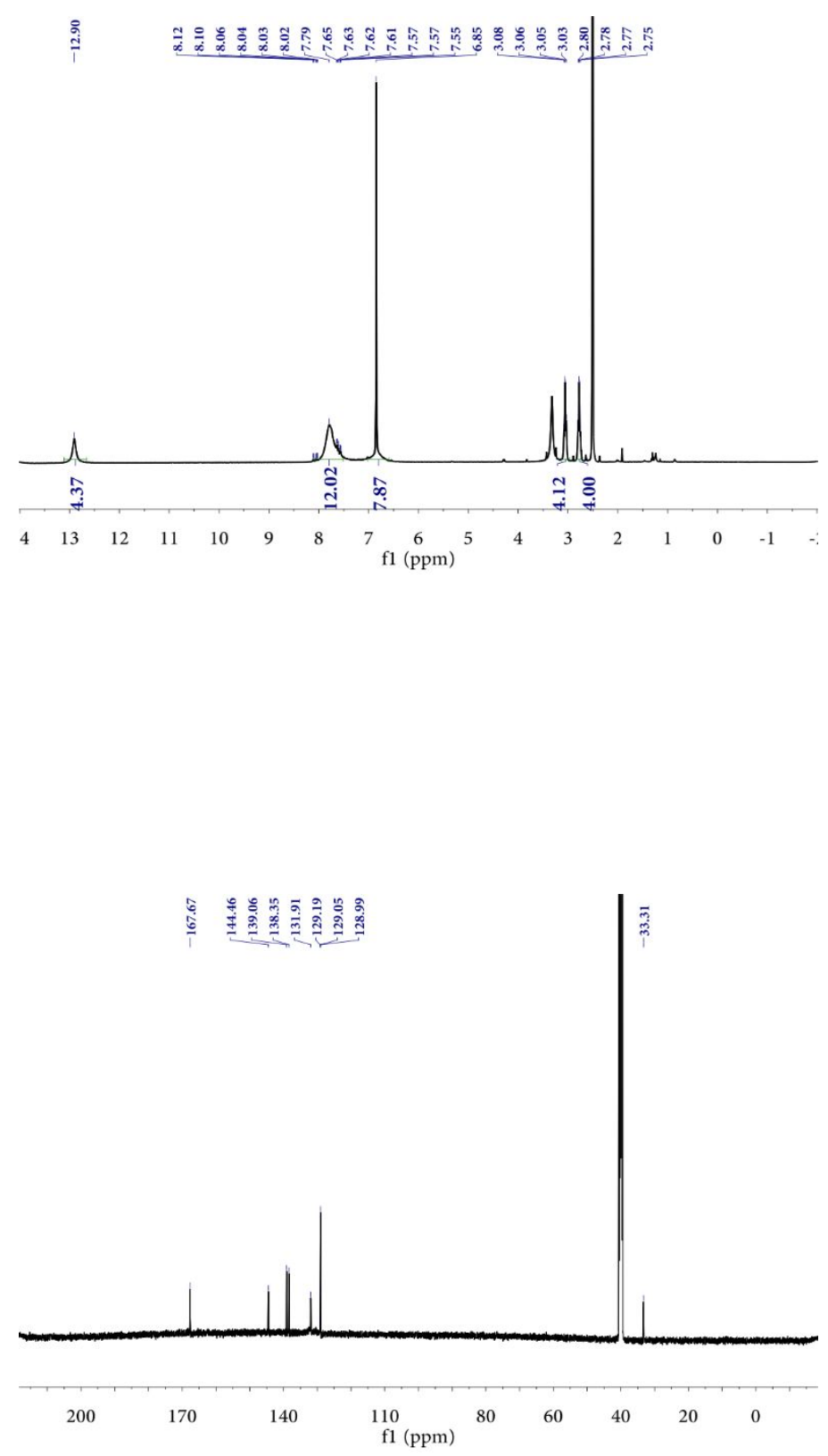


\subsection{Synthesis of Zr-MOFs}

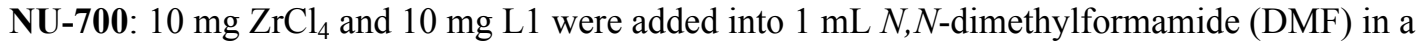
1.5-dram vial. The solution was sonicated for 5 minutes. Then, $400 \mu \mathrm{L}$ of formic acid (HCOOH) was added to the solution and shaken for a few seconds. The vial was placed into a $120^{\circ} \mathrm{C}$ oven for 2 days. Colorless hexagonal thin crystals were collected with $65 \%$ yield based on L1.

NU-405: $10 \mathrm{mg} \mathrm{ZrCl}_{4}$ and $10 \mathrm{mg} \mathrm{L1}$ were added into $1 \mathrm{~mL}$ DMF in a 1.5-dram vial. The solution was sonicated for 5 minutes. Then, $500 \mu \mathrm{L}$ of acetic acid (HAc) was added to the solution and shaken for a few seconds. The vial was placed into a $120{ }^{\circ} \mathrm{C}$ oven for 1 day. Colorless octahedral crystals were collected with $77 \%$ yield based on L1.

NU-1800: $5 \mathrm{mg} \mathrm{ZrCl}_{4}$ and $5 \mathrm{mg} \mathrm{L} 2$ were added into $1 \mathrm{~mL} \mathrm{DMF}$ in a 1.5-dram vial. The solution was sonicated for 5 minutes. Then, $0.12 \mathrm{~mL}$ of HAc was added to the solution and shaken for a few seconds. The vial was placed into a $120{ }^{\circ} \mathrm{C}$ oven for 3 days. Colorless octahedral crystals were collected with $84 \%$ yield based on $\mathrm{L} 2$.

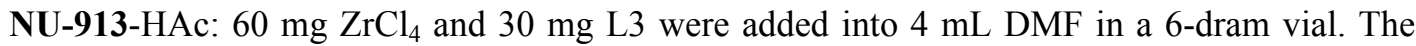
solution was sonicated for 5 minutes. Then, $2 \mathrm{~mL}$ of HAc was added to the solution and shaken for a few seconds. The vial was placed into a $120^{\circ} \mathrm{C}$ oven for 2 days. White powders and small amounts of rod-shaped crystals were collected with $60 \%$ yield based on L3.

NU-913-TFA: $60 \mathrm{mg} \mathrm{ZrCl}_{4}$ and $30 \mathrm{mg} \mathrm{L3}$ were added into $10 \mathrm{~mL} \mathrm{DMF}$ in a 6-dram vial. The solution was sonicated for 5 minutes. Then, $1 \mathrm{~mL}$ of trifluoroacetic acid (TFA) was added to the solution and shaken for a few seconds. The vial was placed into a $120^{\circ} \mathrm{C}$ oven for 2 days. White powders were collected with $75 \%$ yield based on L3.

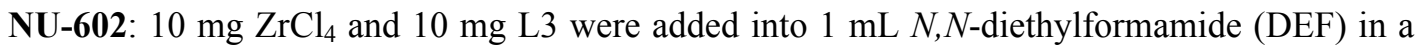
1.5-dram vial. The solution was sonicated for 5 minutes. Then, $500 \mu \mathrm{L}$ of HAc was added to the solution and shaken for a few seconds. The vial was placed into a $120^{\circ} \mathrm{C}$ oven for 2 days. Colorless cubic crystals were collected with $89 \%$ yield based on L3. 


\section{Table S1. Crystal data and structure refinements}

\begin{tabular}{|c|c|c|}
\hline Identification Code & NU-700 & NU-405 \\
\hline Empirical formula & $\mathrm{C}_{138} \mathrm{H}_{102} \mathrm{O}_{32} \mathrm{Zr}_{6}$ & $\mathrm{C}_{90} \mathrm{H}_{24} \mathrm{O}_{16} \mathrm{Zr}_{3}$ \\
\hline Formula weight & 2819.52 & 1634.75 \\
\hline Temperature (K) & $100(2) \mathrm{K}$ & $100(2) \mathrm{K}$ \\
\hline Crystal system & Trigonal & Cubic \\
\hline Space group & $P-3 \mathrm{c} 1$ & $P n-3$ \\
\hline Unit cell dimensions & $\begin{array}{l}a=23.6267(4) \AA \alpha=90^{\circ} \\
b=23.6267(4) \AA \beta=90^{\circ} \\
c=48.2982(18) \AA \gamma=120^{\circ}\end{array}$ & $\begin{array}{l}a=33.03950(10) \AA \alpha=90^{\circ} \\
b=33.03950(10) \AA \beta=90^{\circ} \\
c=33.03950(10) \AA \gamma=90^{\circ}\end{array}$ \\
\hline Volume $\left(\AA^{3}\right), Z$ & 23349.0(12), 4 & $36066.2(3), 8$ \\
\hline $\begin{array}{l}\text { Density (calculated) } \\
\left(\mathrm{mg} / \mathrm{m}^{3}\right)\end{array}$ & 0.802 & 0.602 \\
\hline $\begin{array}{l}\text { Absorption } \\
\text { coefficient }\left(\mathrm{mm}^{-1}\right)\end{array}$ & 3.431 & 1.639 \\
\hline$F(000)$ & 17296 & 6496 \\
\hline $\begin{array}{l}\text { Reflections collected } \\
\text { / unique }\end{array}$ & $43980 / 4994$ & $45571 / 12719$ \\
\hline $\begin{array}{l}\text { Completeness to } \\
\text { theta }\end{array}$ & $41.272 / 97.5 \%$ & $67.679 / 99.9 \%$ \\
\hline$R_{\text {int }}$ & 0.1122 & 0.0345 \\
\hline Refinement method & Full-matrix least-squares on $F^{\wedge} 2$ & Full-matrix least-squares on $F^{\wedge} 2$ \\
\hline $\begin{array}{l}\text { Data / restraints / } \\
\text { parameters }\end{array}$ & 4994 / 1652 / 309 & $12719 / 1059 / 316$ \\
\hline $\begin{array}{l}\text { Goodness-of-fit on } \\
\mathrm{F}^{2}\end{array}$ & 1.108 & 1.095 \\
\hline $\begin{array}{l}\text { Final } R \text { indices } \\
{[\mathrm{I}>2 \operatorname{sigma}(\mathrm{I})]}\end{array}$ & $R_{1}=0.1558, w R_{2}=0.4015$ & $R_{1}=0.1829, w R_{2}=0.5207$ \\
\hline$R$ indices (all data) & $R_{1}=0.1719, w R_{2}=0.4130$ & $R_{1}=0.2027, w R_{2}=0.5538$ \\
\hline $\begin{array}{l}\text { Largest diff. peak } \\
\text { and hole }\left(\mathrm{e} . \AA^{-3}\right)\end{array}$ & $1.609 /-1.272$ & $2.595 /-4.283$ \\
\hline
\end{tabular}




\section{Table S2. Crystal data and structure refinement}

\begin{tabular}{|c|c|c|c|}
\hline Identification Code & NU-1800 & NU-913 & NU-602 \\
\hline Empirical formula & $\mathrm{C}_{44} \mathrm{H}_{28} \mathrm{O}_{16} \mathrm{Zr}_{3}$ & $\mathrm{C}_{44} \mathrm{H}_{28} \mathrm{O}_{16} \mathrm{Zr}_{3}$ & $\mathrm{C}_{33} \mathrm{H}_{18} \mathrm{Hf}_{3} \mathrm{O}_{16}$ \\
\hline Formula weight & 1086.32 & 1086.32 & 1205.94 \\
\hline Temperature (K) & $100(2) \mathrm{K}$ & $100(2) \mathrm{K}$ & $100(2) \mathrm{K}$ \\
\hline Crystal system & Orthorhombic & Orthorhombic & Cubic \\
\hline Space group & $F \mathrm{mmm}$ & $\mathrm{Cmmm}$ & $P \mathrm{~m}-3 \mathrm{~m}$ \\
\hline Unit cell dimensions & $\begin{array}{l}a=19.7633(2) \AA \alpha=90^{\circ} \\
b=26.0683(2) \AA \beta=90^{\circ} \\
c=35.3983(3) \AA \gamma=90^{\circ}\end{array}$ & $\begin{array}{l}a=25.9052(10) \AA \alpha=90^{\circ} \\
b=32.1806(17) \AA \beta=90^{\circ} \\
c=12.2659(5) \AA \gamma=90^{\circ}\end{array}$ & $\begin{array}{l}a=33.0234(5) \AA \alpha=90^{\circ} \\
b=33.0234(5) \AA \beta=90^{\circ} \\
c=33.0234(5) \AA \gamma=90^{\circ}\end{array}$ \\
\hline Volume $\left(\AA^{3}\right), Z$ & 18237.1(3), 8 & 10225.4(8), 4 & $36013.5(16), 16$ \\
\hline $\begin{array}{l}\text { Density (calculated) } \\
\left(\mathrm{mg} / \mathrm{m}^{3}\right)\end{array}$ & 0.791 & 0.706 & 0.890 \\
\hline $\begin{array}{l}\text { Absorption } \\
\text { coefficient }\left(\mathrm{mm}^{-1}\right)\end{array}$ & 3.352 & 2.993 & 6.491 \\
\hline$F(000)$ & 6560 & 3208 & 8961 \\
\hline $\begin{array}{l}\text { Reflections collected } \\
\text { / unique }\end{array}$ & $24907 / 5072$ & $10922 / 3106$ & $42843 / 4588$ \\
\hline $\begin{array}{l}\text { Completeness to } \\
\text { theta }\end{array}$ & $67.684 / 99.8 \%$ & $51.670 / 98.7 \%$ & $56.841 / 98.6 \%$ \\
\hline$R_{\text {int }}$ & 0.0242 & 0.0440 & 0.0361 \\
\hline Refinement method & Full-matrix least-squares on $F^{\wedge} 2$ & Full-matrix least-squares on $F^{\wedge} 2$ & Full-matrix least-squares on $F^{\wedge} 2$ \\
\hline $\begin{array}{l}\text { Data / restraints / } \\
\text { parameters }\end{array}$ & $5072 / 0 / 152$ & $3106 / 0 / 153$ & 4588 / $285 / 202$ \\
\hline $\begin{array}{l}\text { Goodness-of-fit on } \\
\mathrm{F}^{2}\end{array}$ & 1.076 & 1.090 & 1.118 \\
\hline $\begin{array}{l}\text { Final } R \text { indices } \\
{[\mathrm{I}>2 \operatorname{sigma}(\mathrm{I})]}\end{array}$ & $R_{I}=0.0341, w R_{2}=0.1012$ & $R_{l}=0.0646, w R_{2}=0.1938$ & $R_{1}=0.1257, w R_{2}=0.4299$ \\
\hline$R$ indices (all data) & $R_{1}=0.0355, w R_{2}=0.1023$ & $R_{1}=0.0746, w R_{2}=0.2009$ & $R_{1}=0.1457, w R_{2}=0.4802$ \\
\hline $\begin{array}{l}\text { Largest diff. peak } \\
\text { and hole }\left(\mathrm{e} . \AA^{-3}\right)\end{array}$ & $0.824 /-1.049$ & $1.608 /-0.968$ & $1.034 /-1.149$ \\
\hline
\end{tabular}




\section{Figures S1-S15. X-ray crystallographic structures of reported Zr-MOFs}

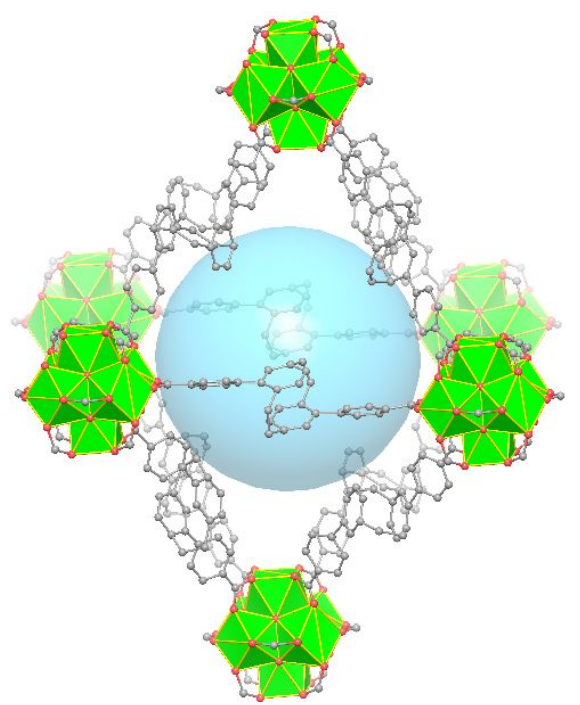

Figure S1. Octahedral cage in NU-700 with the cavity highlighted by cyan sphere. Color code: gray: C; red: O; green: Zr.

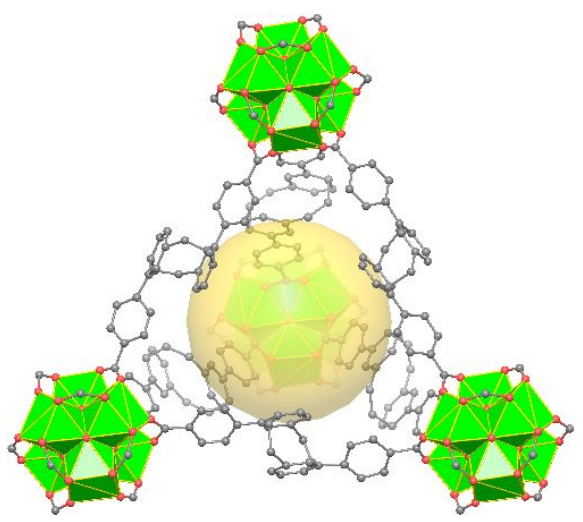

Figure S2. Tetrahedral cage in NU-700 with the cavity highlighted by yellow sphere. Color code: gray: C; red: O; green: Zr.

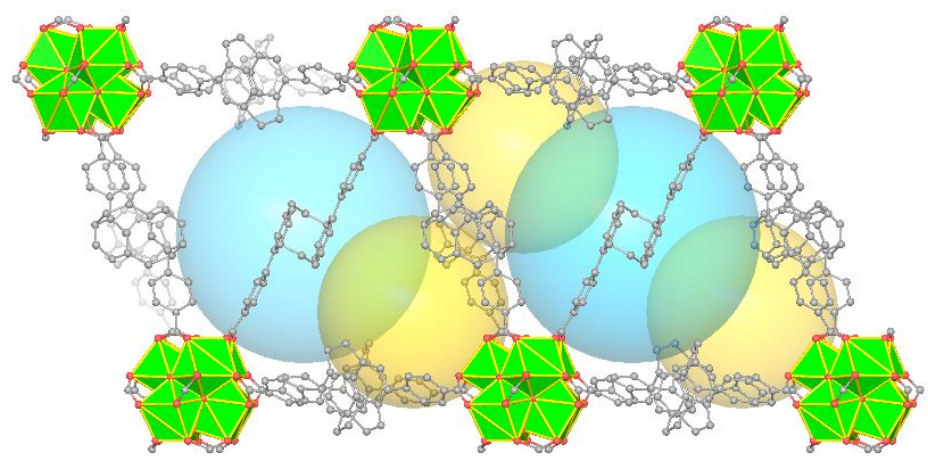

Figure S3. 2D structure of NU-700 along the $b$ axis. 


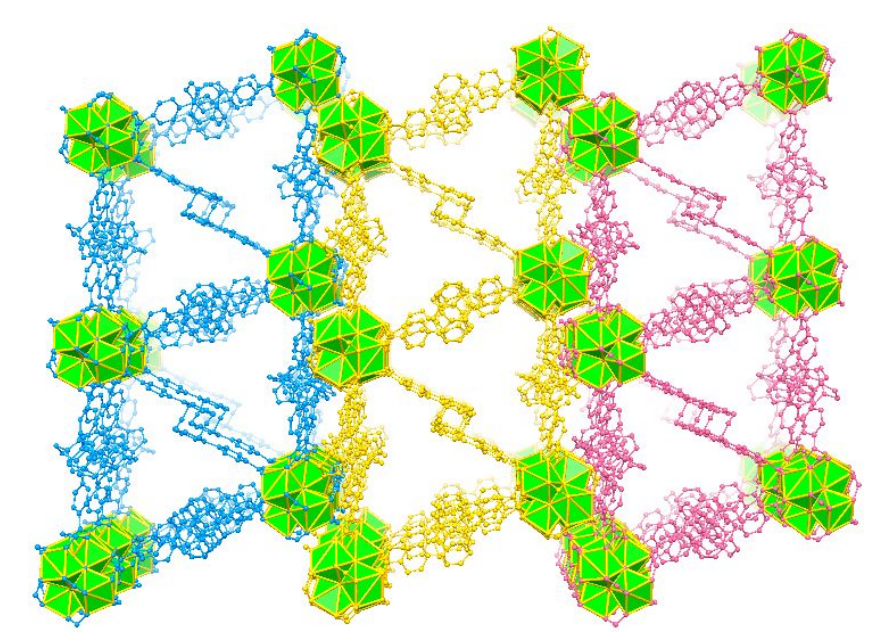

Figure S4. AA packing of the 2D net in NU-700, each net was represented by one color.

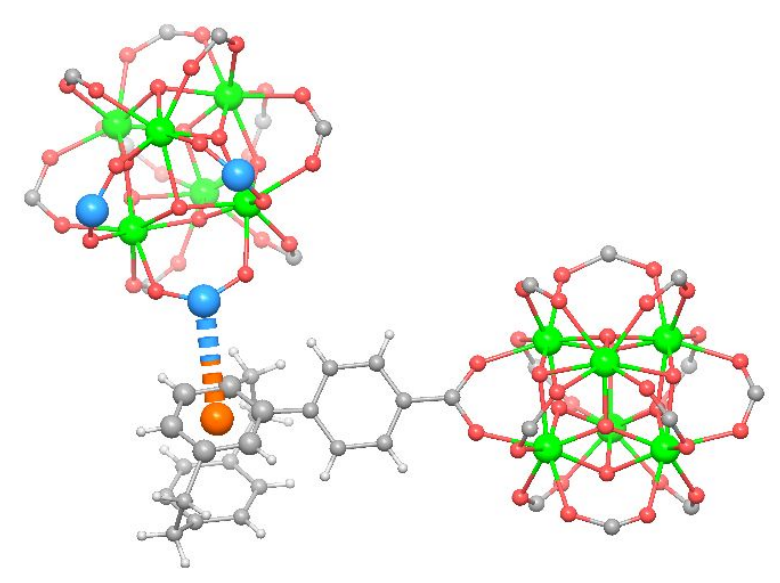

Figure S5. The weak C-H... $\pi$ interactions (distance of $3.53 \AA$ ) formed by capped formic acid groups and benzene ring between 2D layers. Color code: gray: $\mathrm{C}$; red: $\mathrm{O}$; green: $\mathrm{Zr}$; blue: formic acid group. The orange atom is generated in the center of the benzene ring to show the $\mathrm{C}-\mathrm{H} \ldots \pi$ distance.
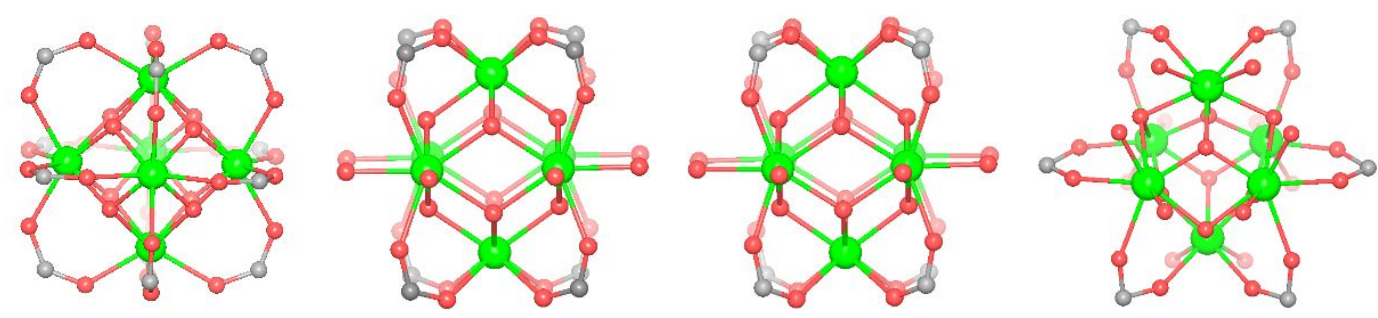

Figure S6. The $\mathrm{Zr}_{6}$ nodes presented in NU-405, NU-1800, NU-913, and NU-602 from left to right. 


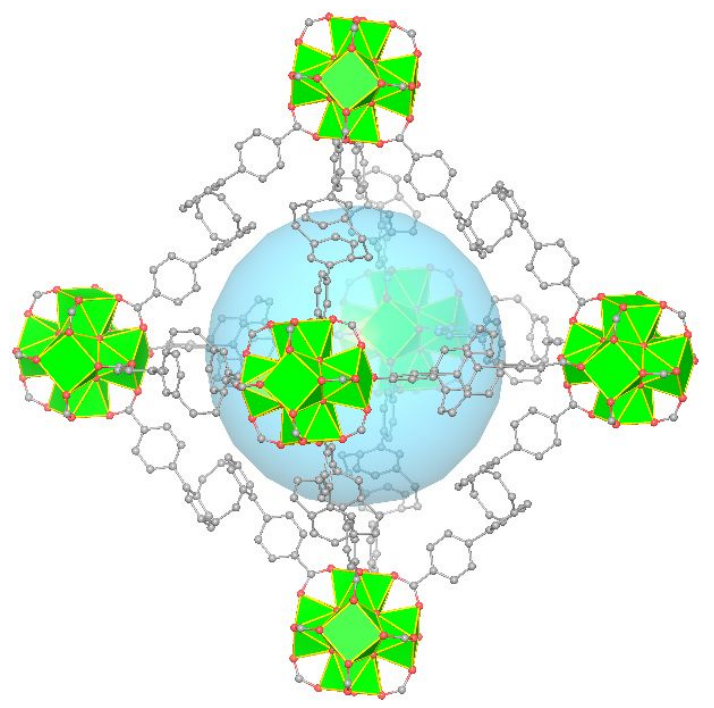

Figure S7. Octahedral cage in NU-405 with the cavity highlighted by a cyan sphere. Color code: gray: C; red: O; green: Zr.

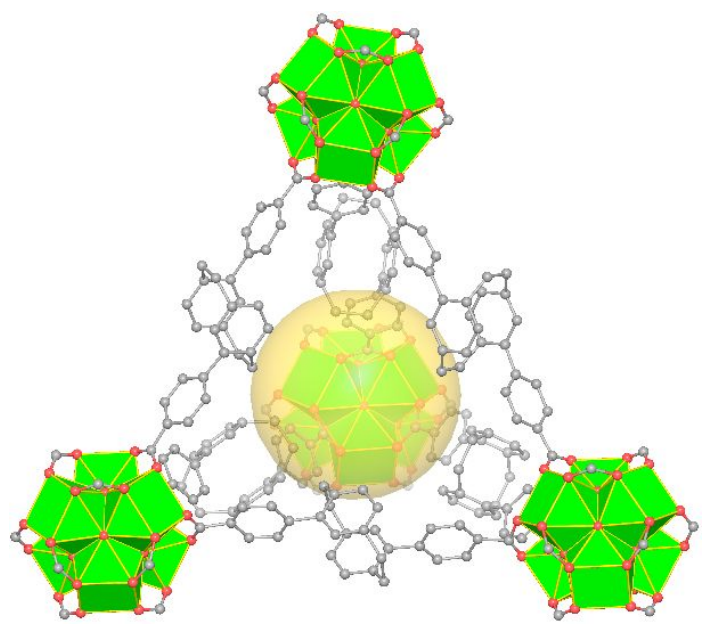

Figure S8. Tetrahedral cage in NU-405 with the cavity highlighted by yellow sphere. Color code: gray: C; red: O; green: Zr. 


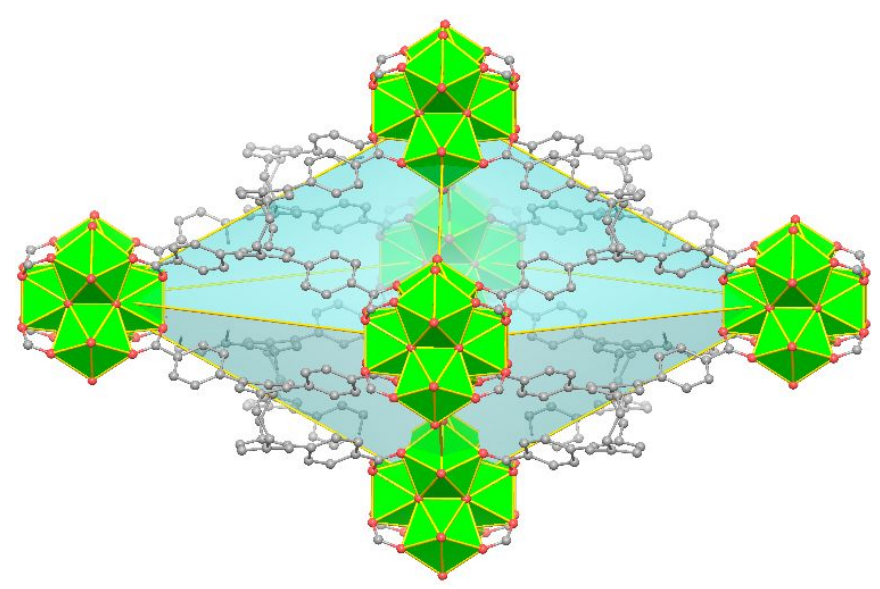

Figure S9. Large octahedral cage in NU-1800. Color code: gray: C; red: O; green: Zr.

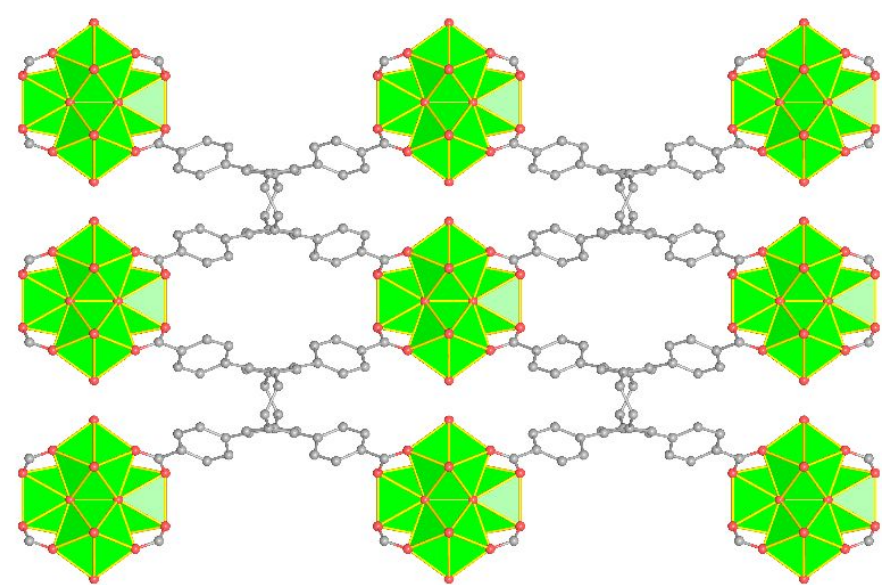

Figure S10. 3D structure of NU-1800 along the b axis. Color code: gray: C; red: O; green: Zr.

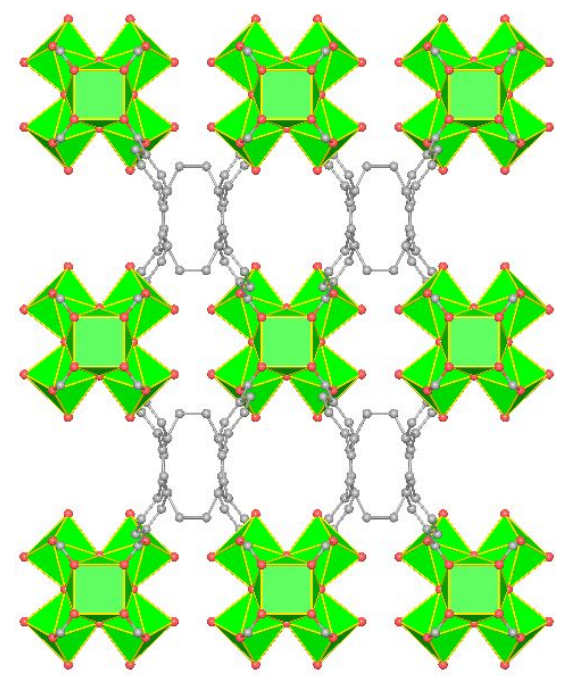

Figure S11. 3D structure of NU-1800 along the c axis. Color code: gray: C; red: O; green: Zr. 


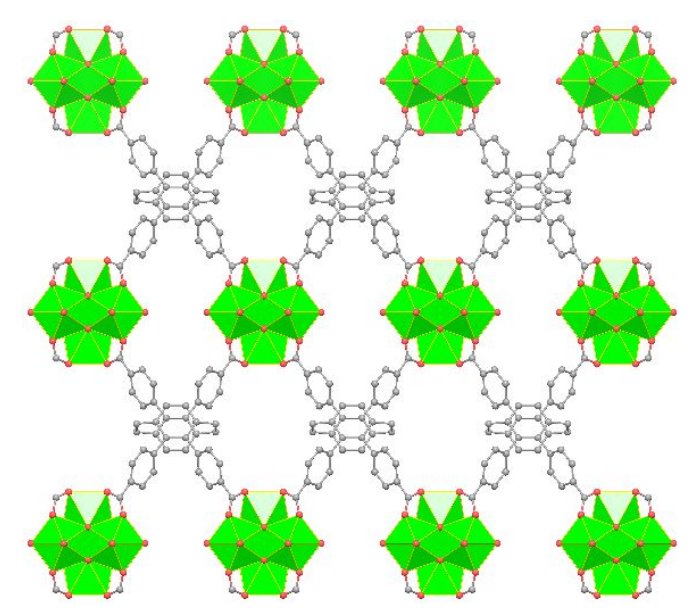

Figure S12. 3D structure of NU-913 along the a axis. Color code: gray: C; red: O; green: Zr.

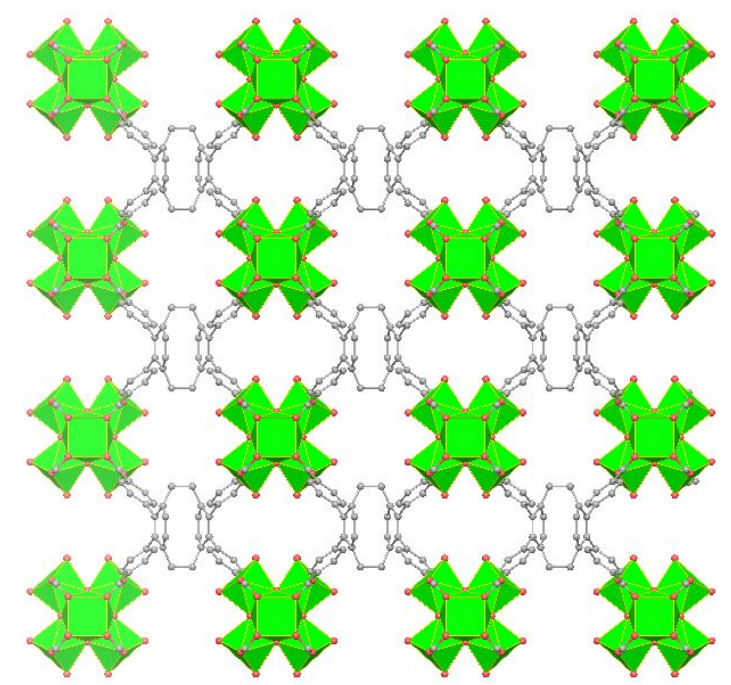

Figure S13. 3D structure of NU-913 along the b axis. Color code: gray: C; red: O; green: Zr.

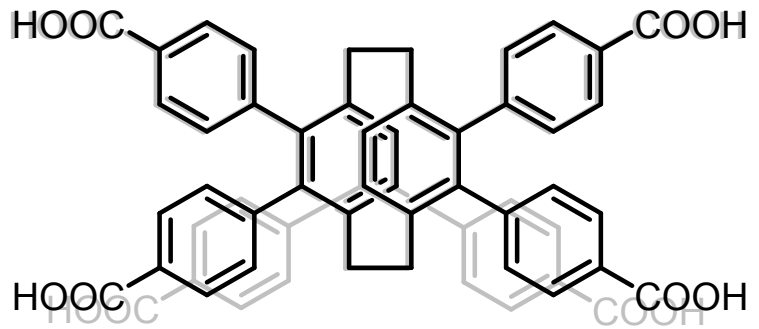

Figure S14. An overlay view of linkers L2 and L3, showing their similarity from an overhead view. 

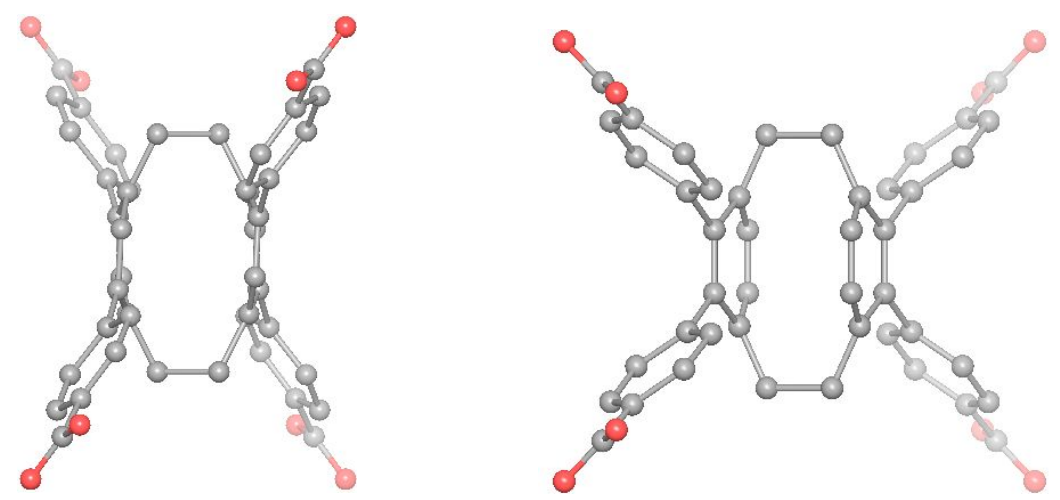

Figure S15. The comparison of linker conformation in NU-1800 (left) and NU-913 (right), showing their similarity. Color code: gray: $\mathrm{C}$; red: $\mathrm{O}$.

6. Figures S16-S18. PXRD patterns of NU-700, NU-405, and NU-1800

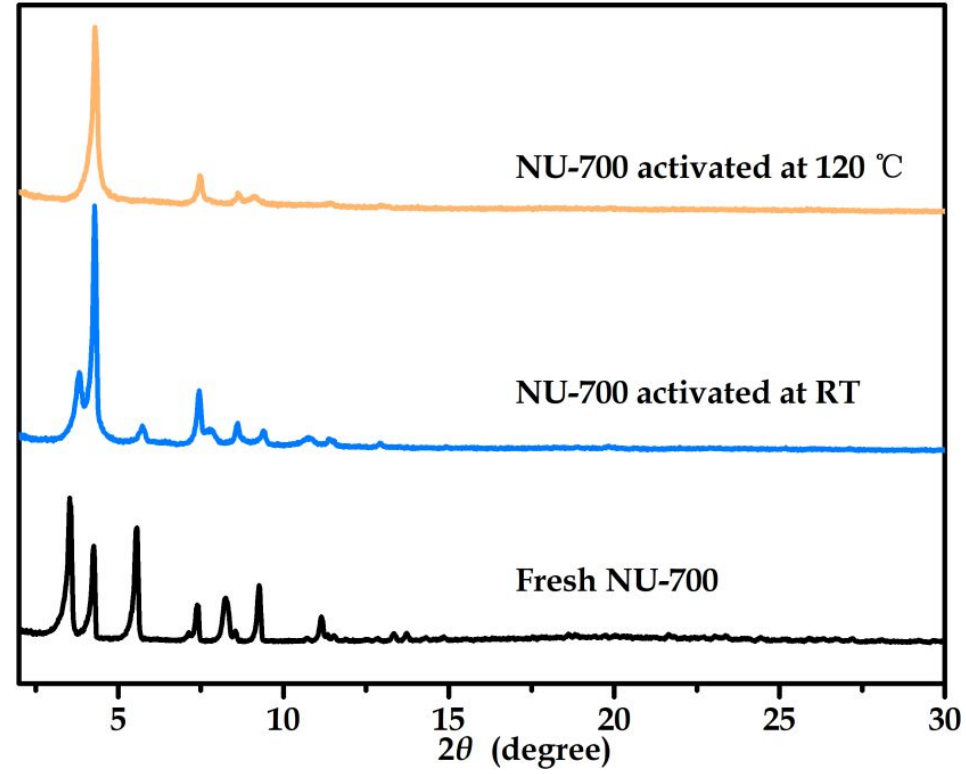

Figure S16. PXRD patterns of NU-700 activated under different temperatures, showing its structure robustness. The loss of the peak centered at 3 degree is due to preferred crystal orientation. 


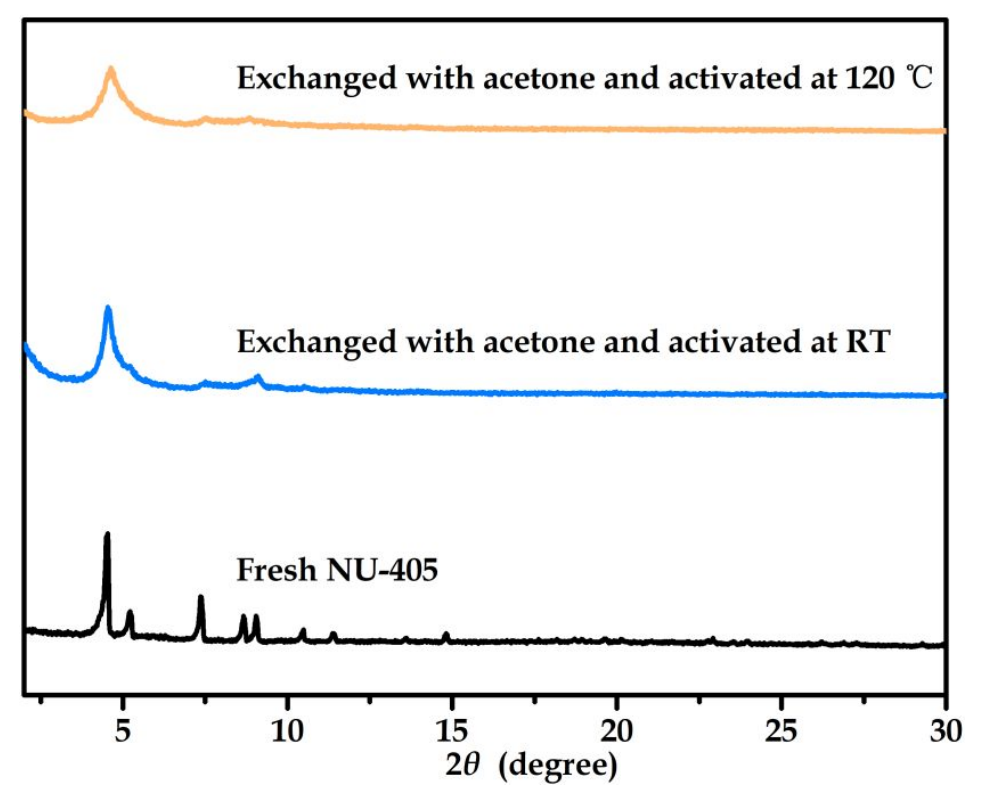

Figure S17. PXRD patterns of NU-405 activated under different temperatures, showing the crystallinity decrease under these conditions.

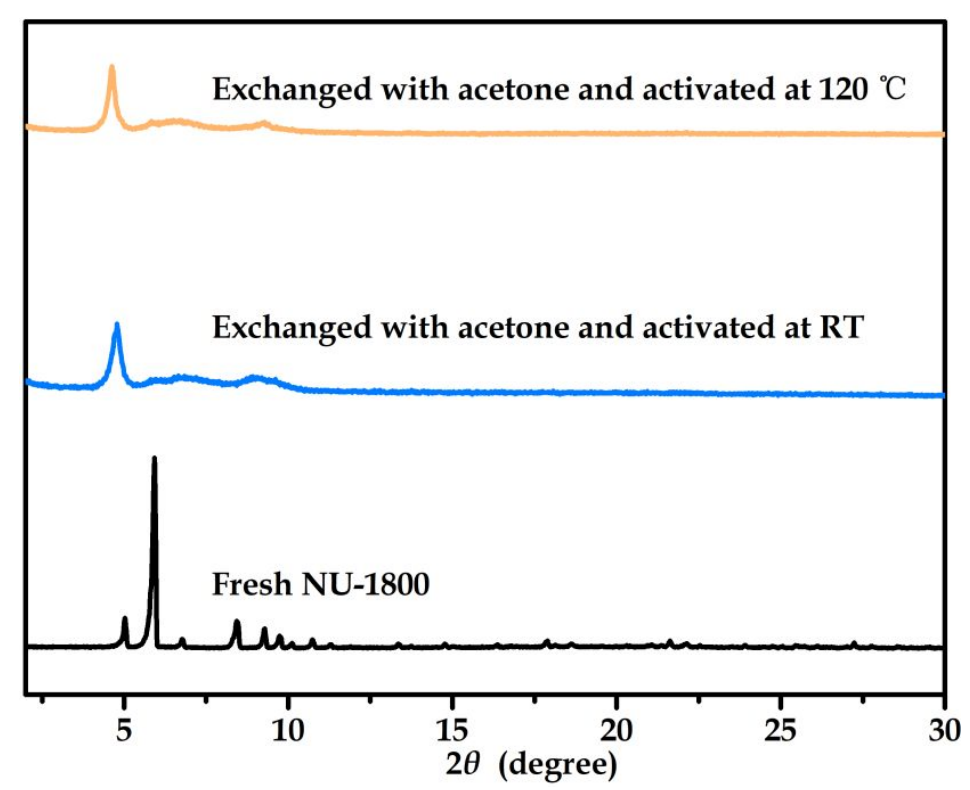

Figure S18. PXRD patterns of NU-1800 activated under different temperatures, showing the crystallinity decrease under these conditions. 
7. Figures S19-S24. $\mathrm{N}_{2}$ sorption isotherms of NU-700, NU-405, and NU-1800

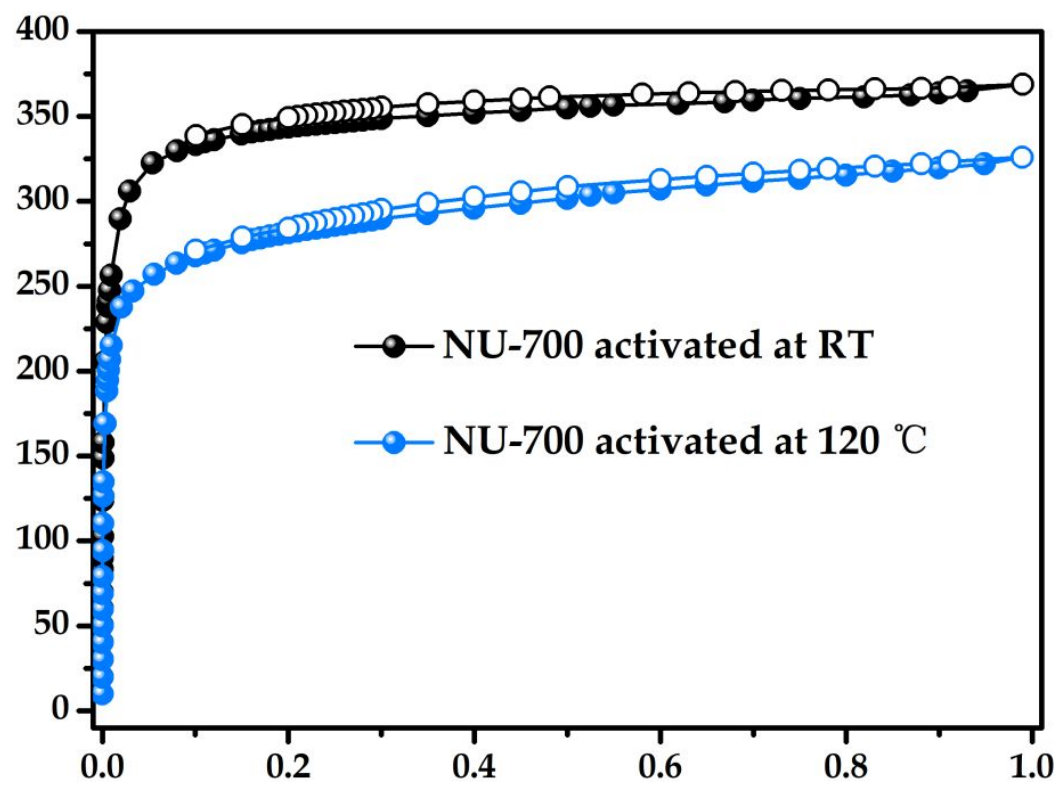

Figure S19. $\mathrm{N}_{2}$ adsorption/desorption isotherms at $77 \mathrm{~K}$ of NU-700 activated under different temperatures.

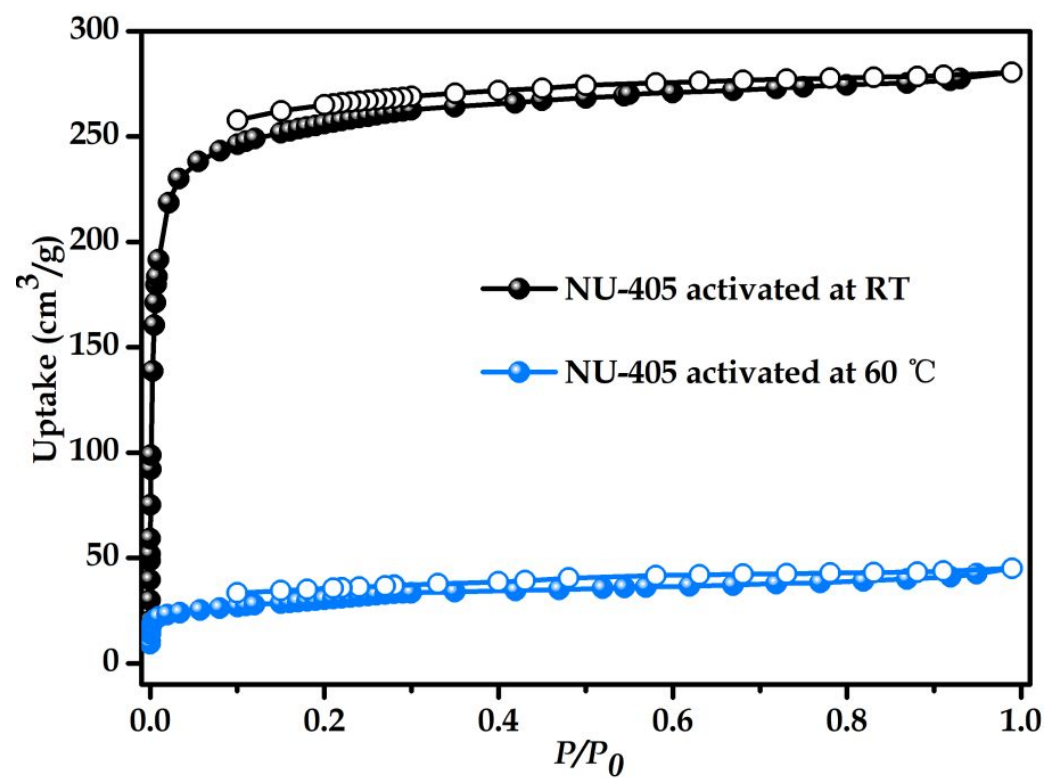

Figure S20. $\mathrm{N}_{2}$ adsorption/desorption isotherms at $77 \mathrm{~K}$ of NU-405 activated under different temperatures. 


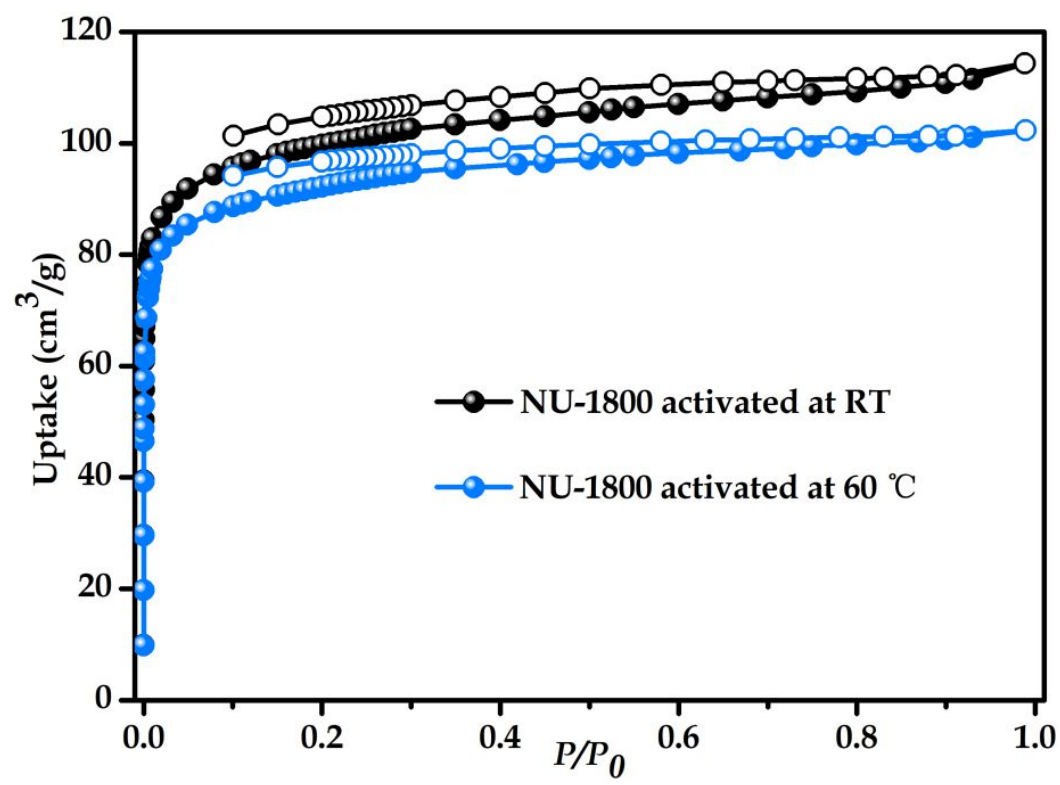

Figure S21. $\mathrm{N}_{2}$ adsorption/desorption isotherms at $77 \mathrm{~K}$ of NU-1800 activated under different temperatures.

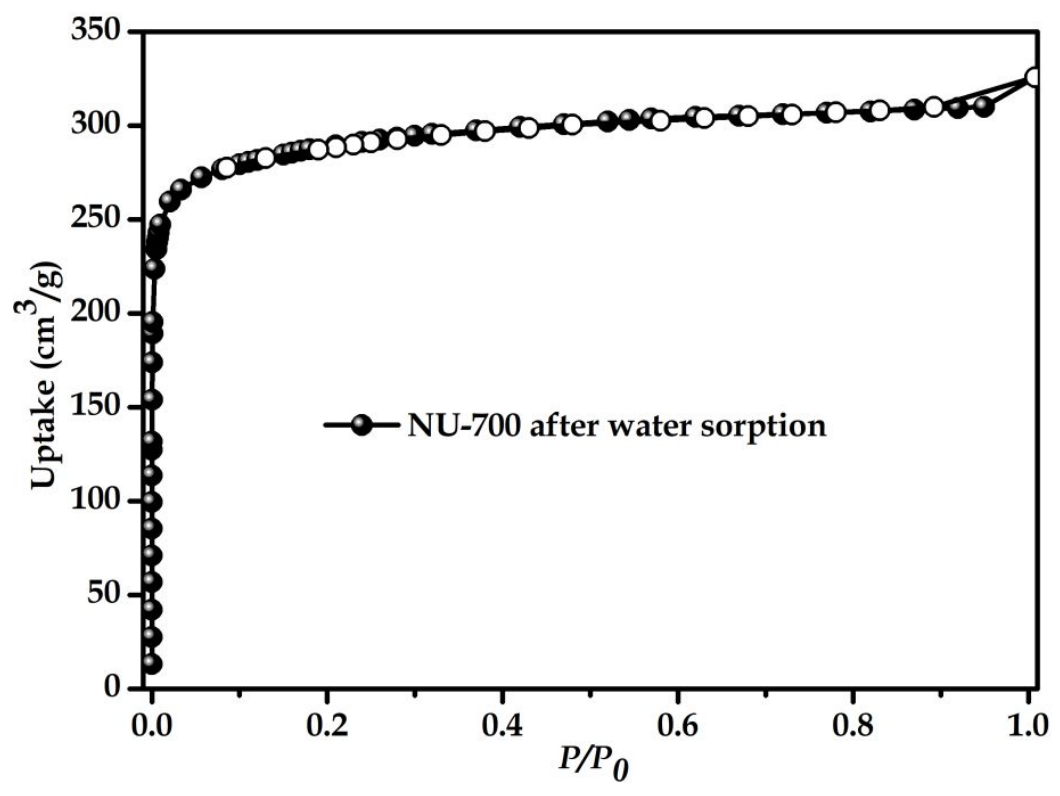

Figure S22. $\mathrm{N}_{2}$ adsorption/desorption isotherms at $77 \mathrm{~K}$ of NU-700 after water sorption. 


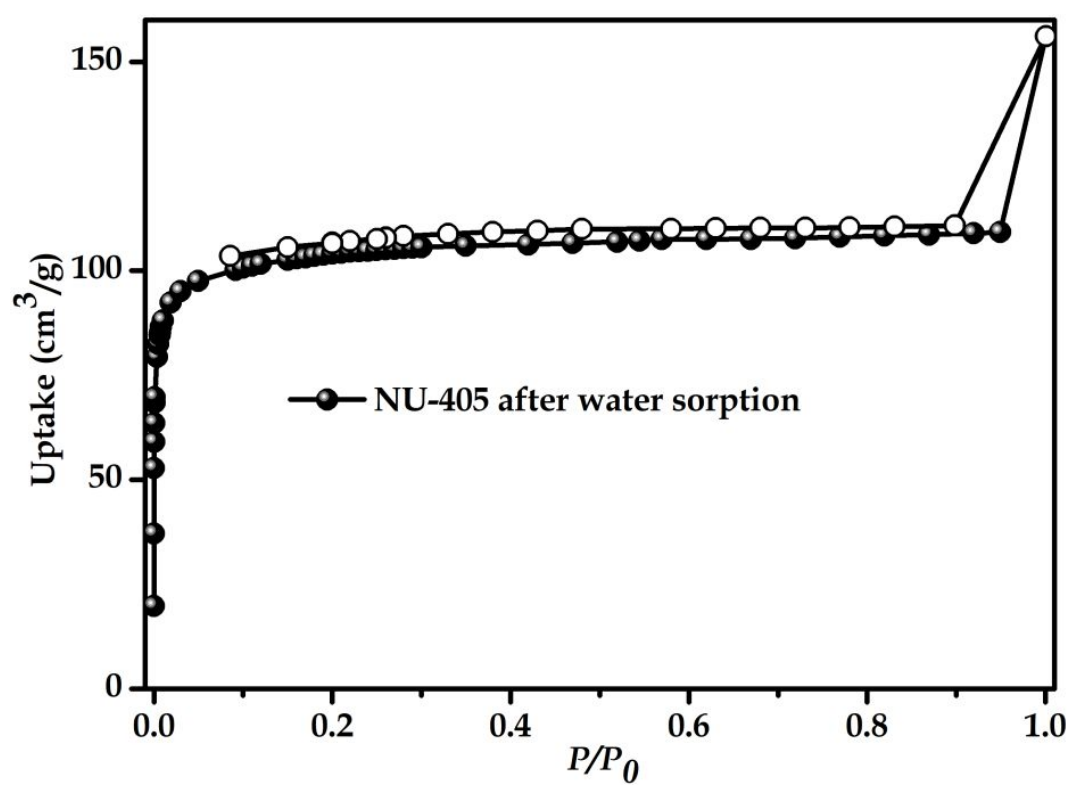

Figure S23. $\mathrm{N}_{2}$ adsorption/desorption isotherms at $77 \mathrm{~K}$ of NU-405 after water sorption.

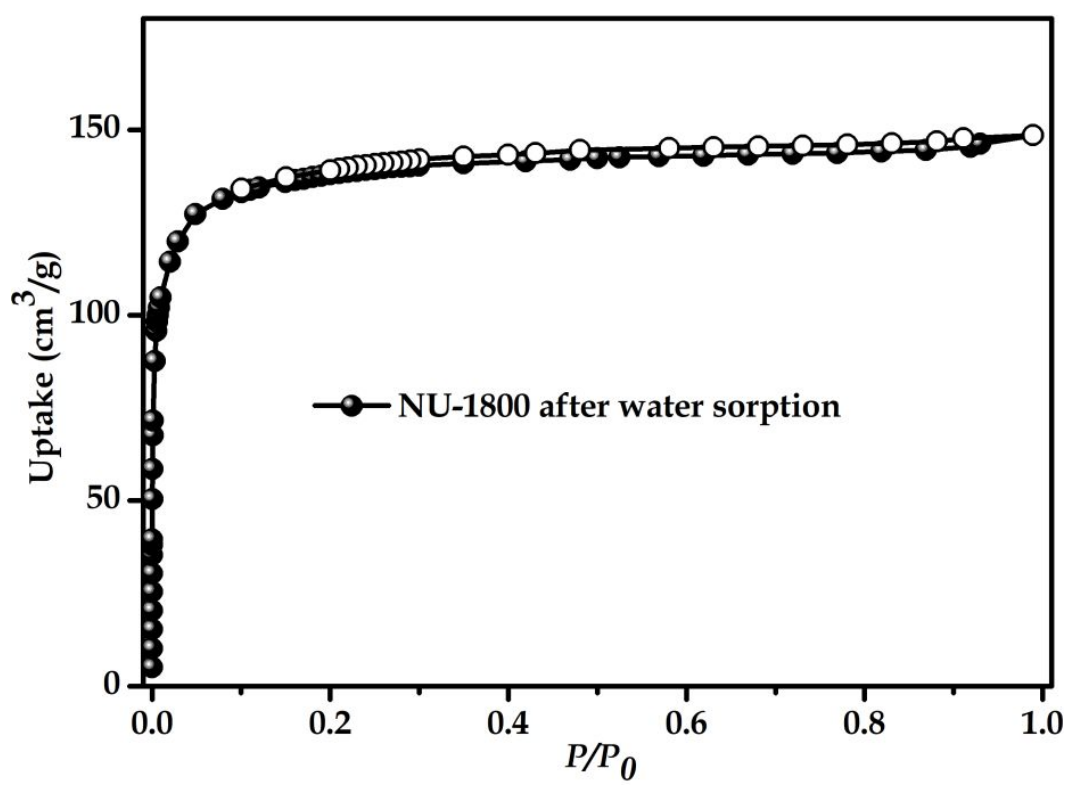

Figure S24. $\mathrm{N}_{2}$ adsorption/desorption isotherms at $77 \mathrm{~K}$ of NU-1800 after water sorption. 
8. Figures S25-S28. Water sorption isotherms of NU-700, NU-405, and NU-1800

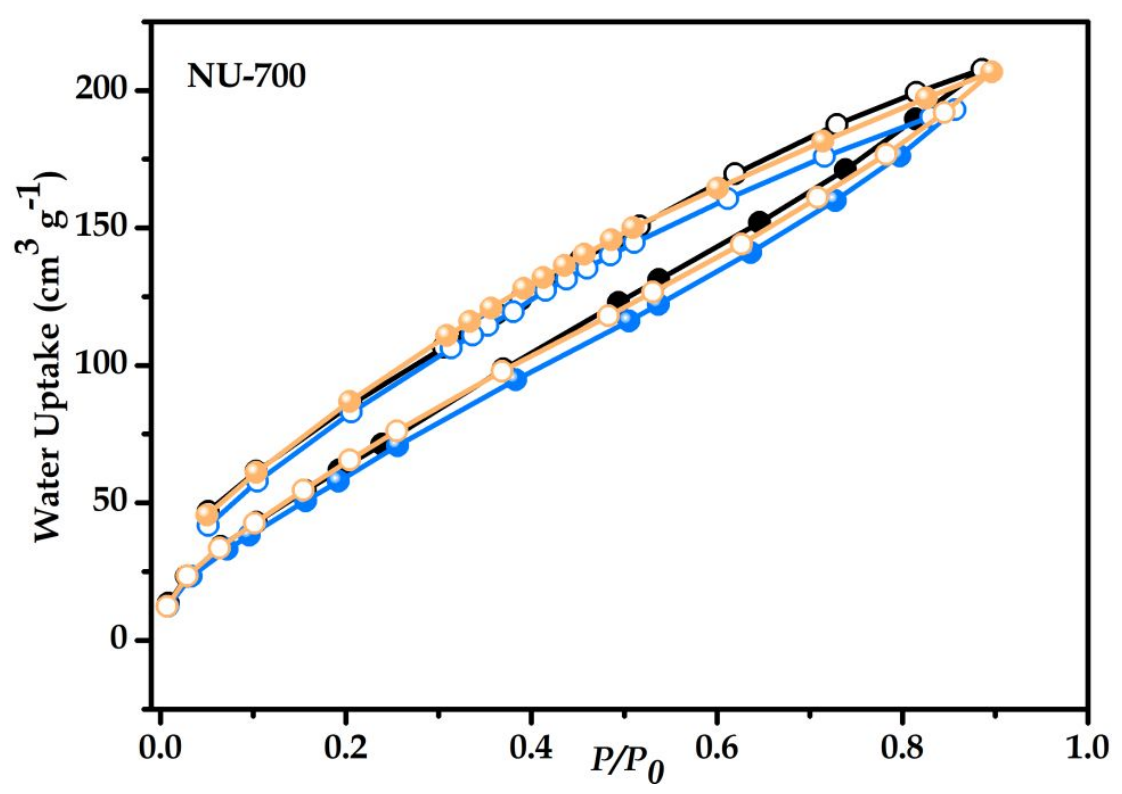

Figure S25. Three water adsorption-desorption cycles of NU-700 at $298 \mathrm{~K}$. The sample was activated under vacuum at RT after each cycle.

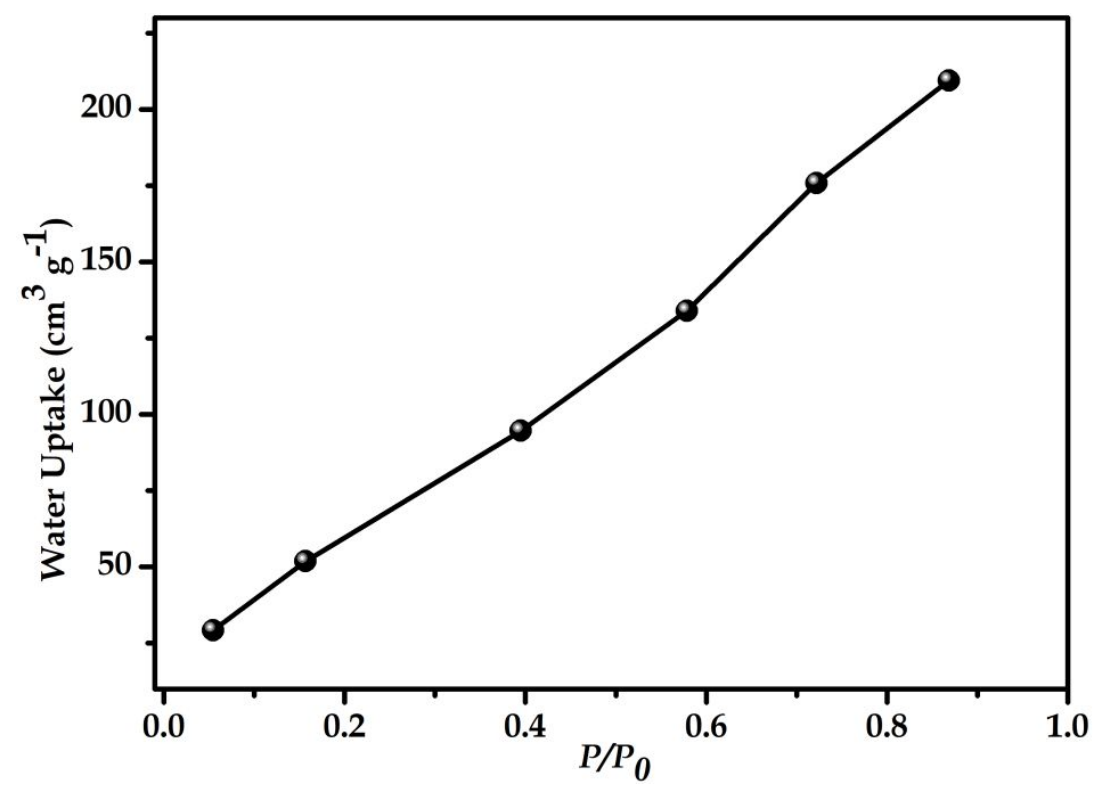

Figure S26. Water adsorption of NU-700 at $298 \mathrm{~K}$ with the equilibrium time of 1000 seconds. 


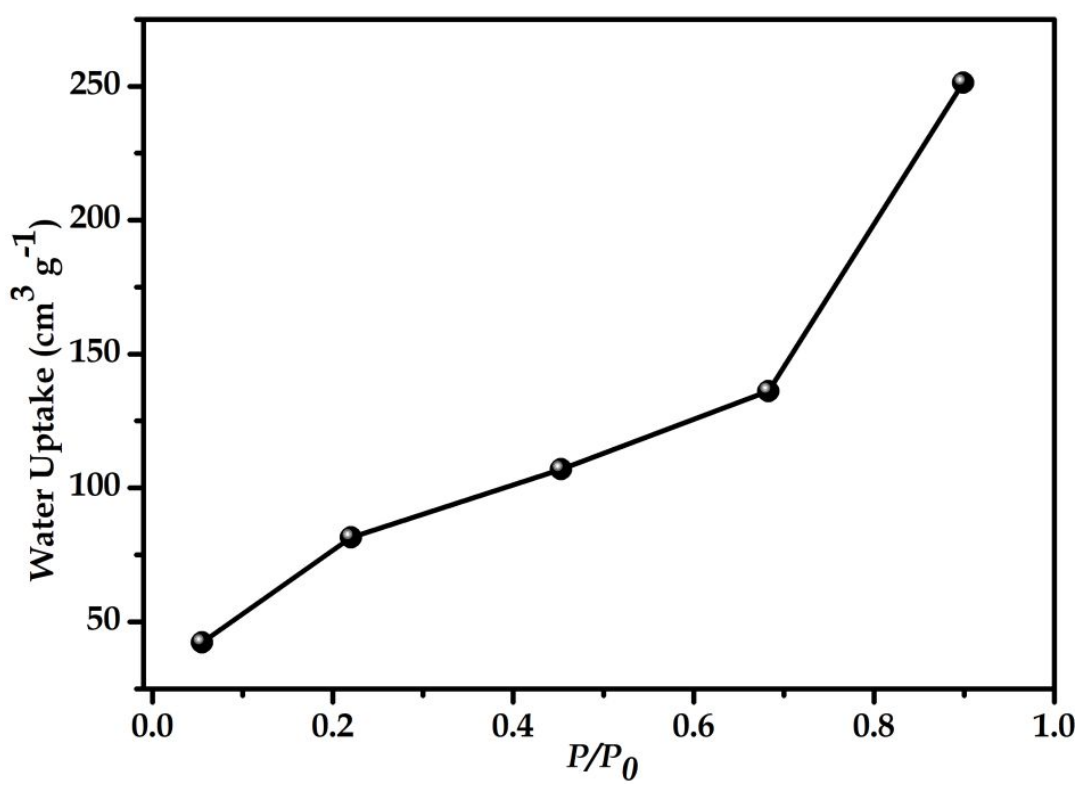

Figure S27. Water adsorption of NU-405 at $298 \mathrm{~K}$ with the equilibrium time of 1000 seconds.

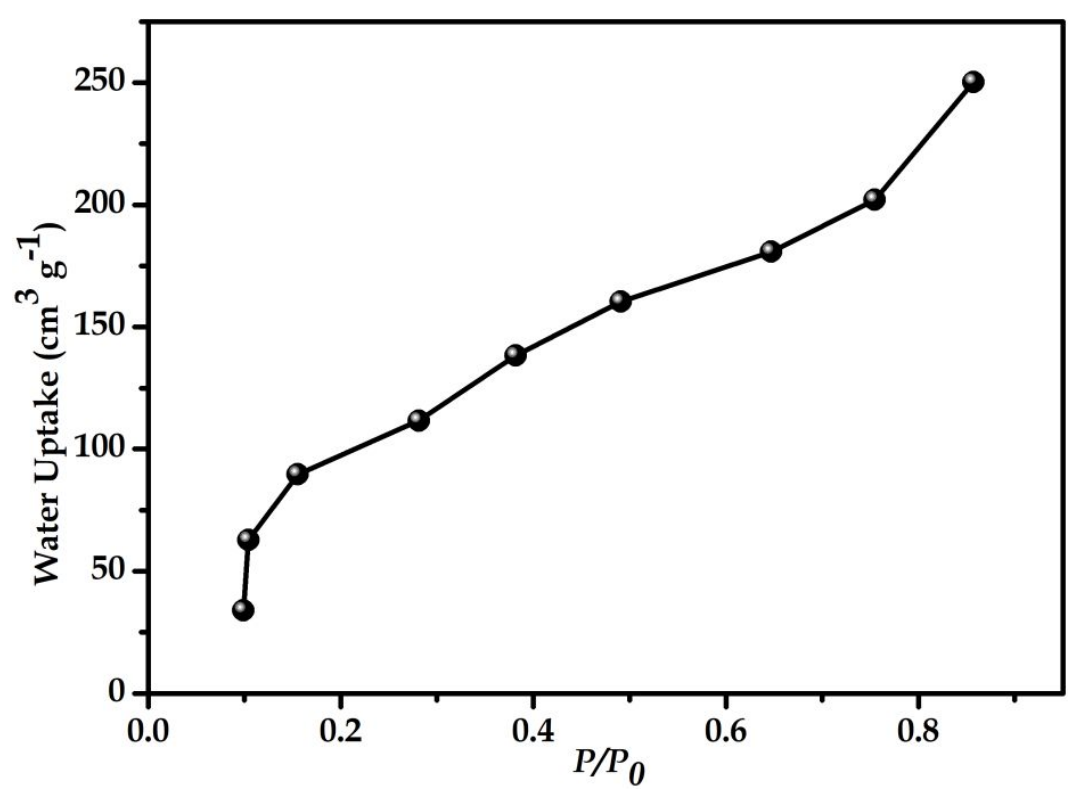

Figure S28. Water adsorption of NU-1800 at $298 \mathrm{~K}$ with the equilibrium time of 1000 seconds. 
9. Figure S29. TGA curves of reported Zr-MOFs

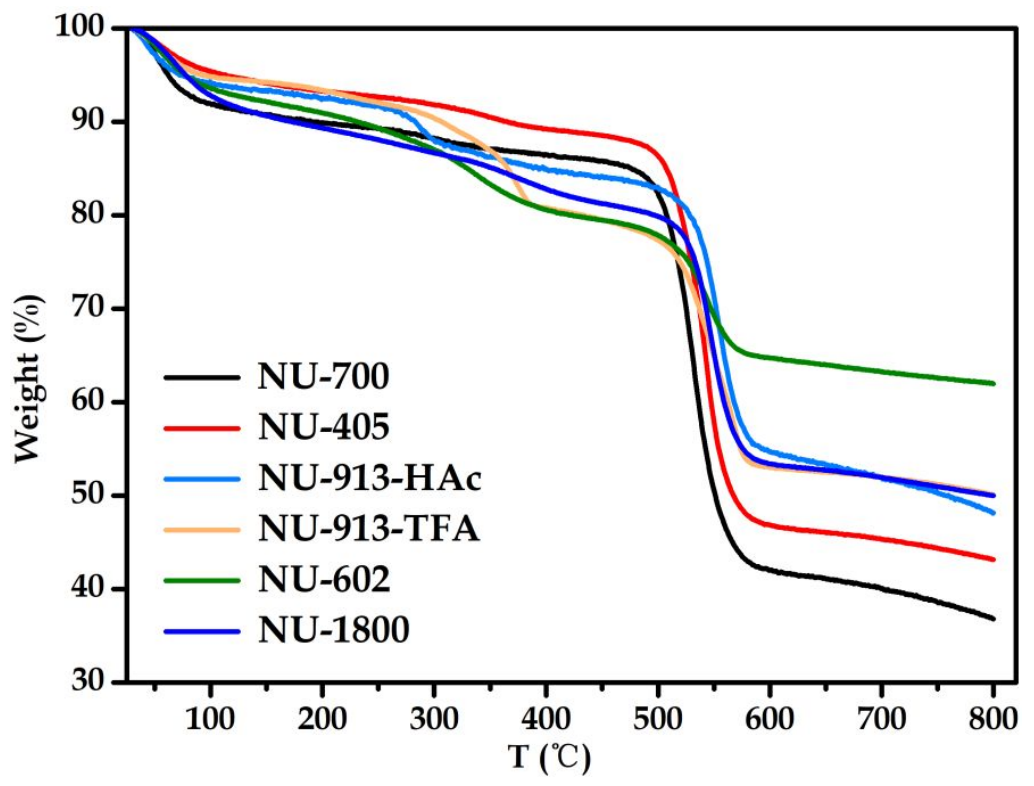

Figure S23. TGA curves of all Zr-MOFs

10. Figures S30-S31. NMR spectra of digested NU-913-HAc and NU-913-TFA

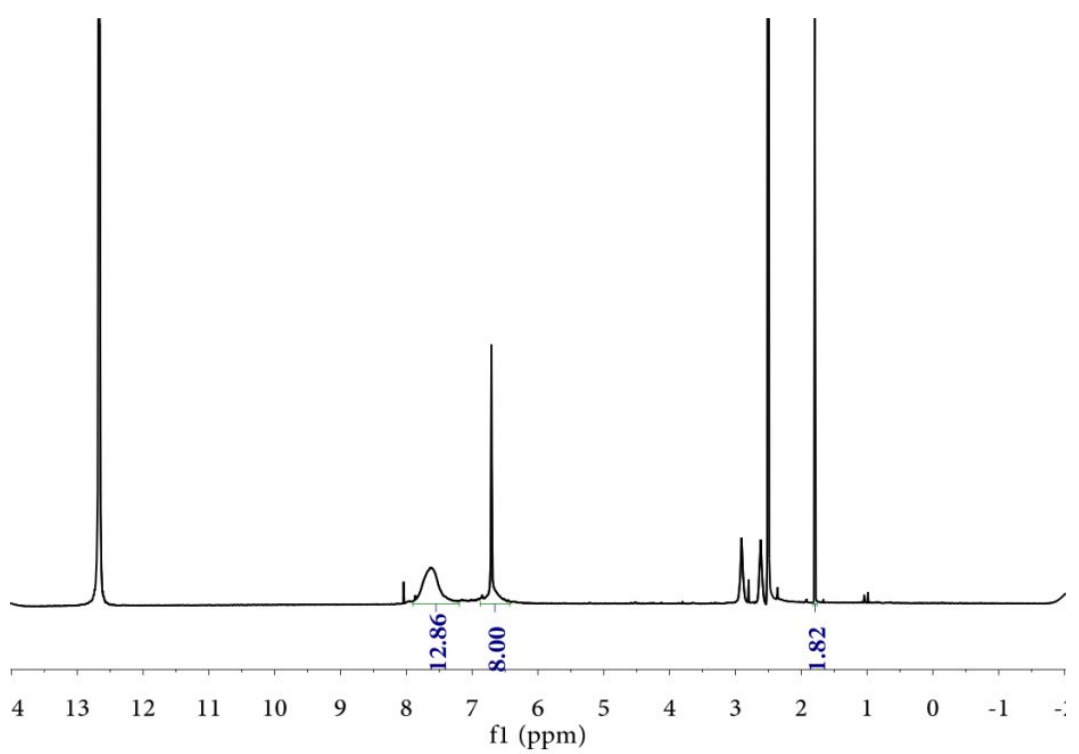

Figure S30. ${ }^{1} \mathrm{H}$ NMR spectrum of acid digested NU-913-HAc, giving rise to $1.33 \mathrm{HAc}$ per $\mathrm{Zr}_{6}$ node. 


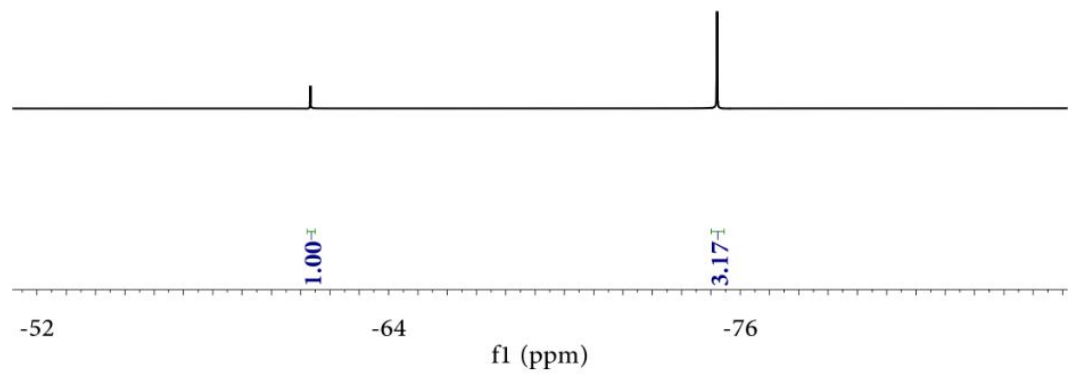

Figure S31. ${ }^{19} \mathrm{~F}$ NMR spectrum of acid digested NU-913-TFA, giving rise to $1.85 \mathrm{TFA}$ per $\mathrm{Zr}_{6}$ node.

\section{Figures S32-S37. SEM images of reported Zr-MOFs}
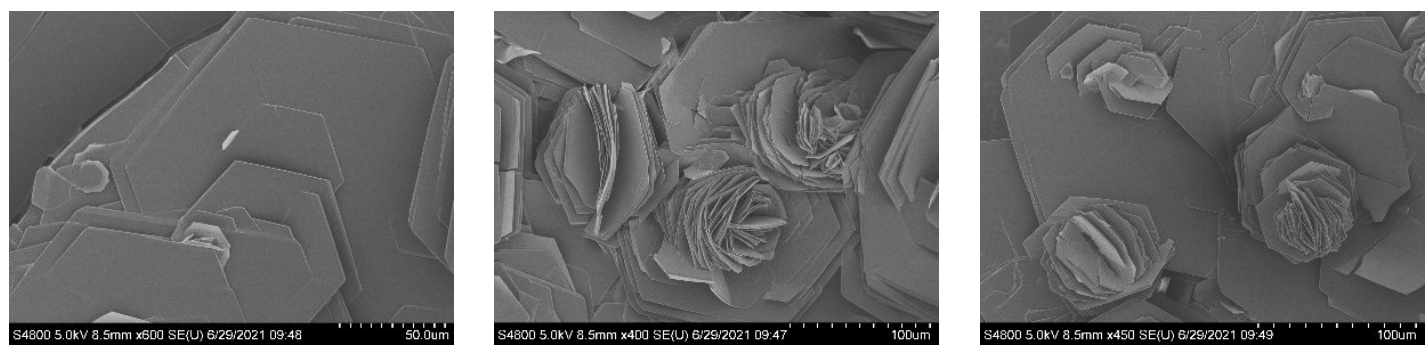

Figure S32. SEM images of NU-700, showing the thin hexagonal morphology.
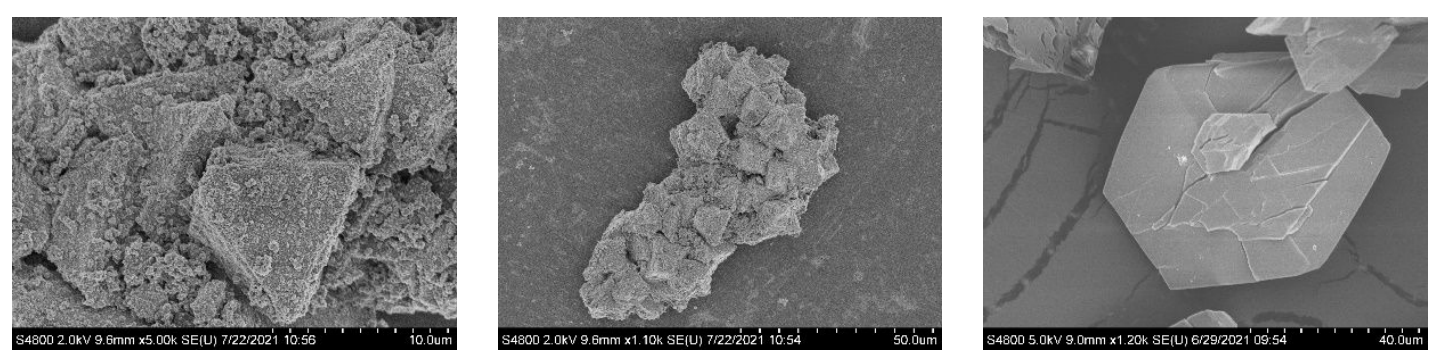

Figure S33. SEM images of NU-405, showing the octahedral morphology. 

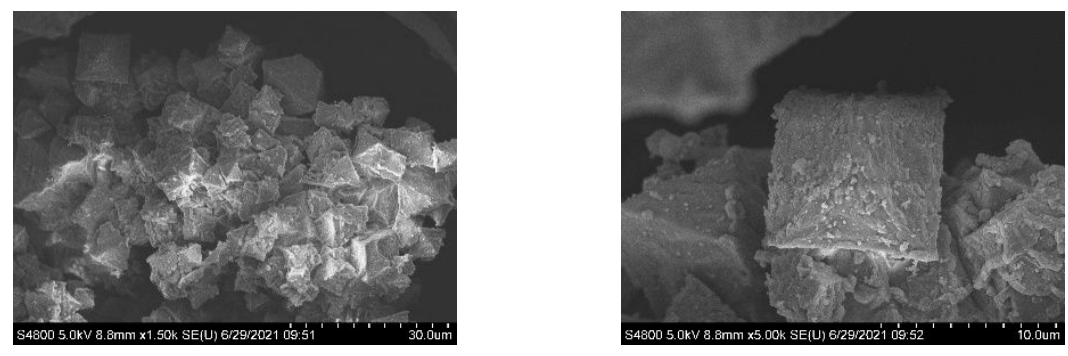

Figure S34. SEM images of NU-1800, showing the octahedral morphology.
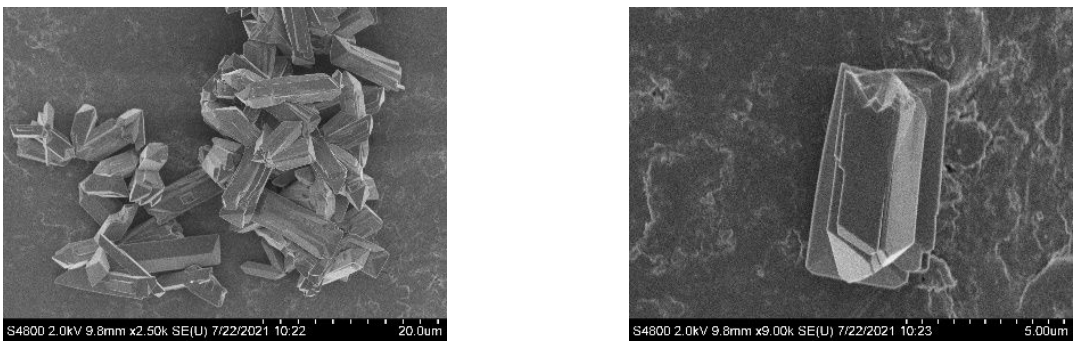

Figure S35. SEM images of NU-913-HAc, showing the rod-shaped morphology.
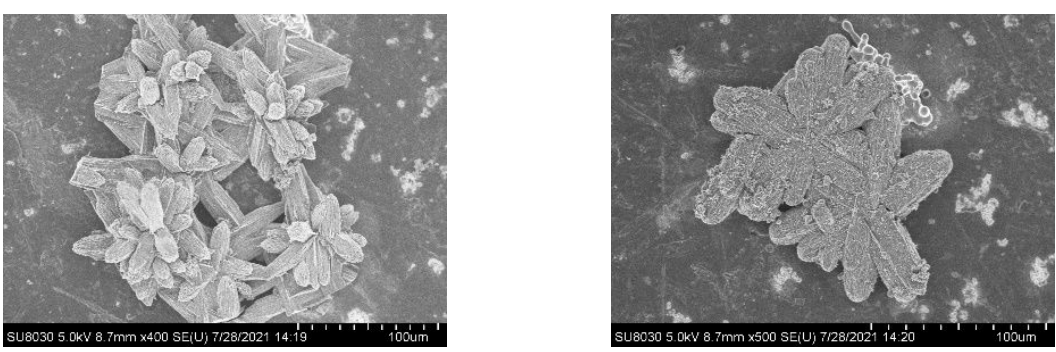

Figure S36. SEM images of NU-913-TFA, showing the rod-shaped morphology.
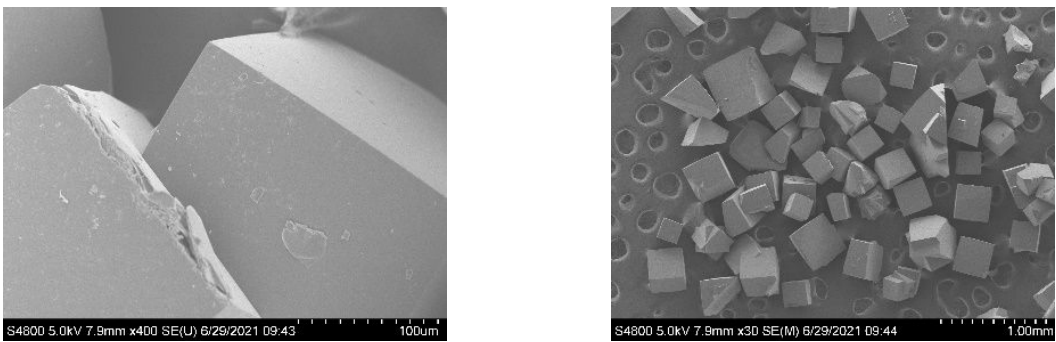

Figure S37. SEM images of NU-602, showing the cubic morphology. 

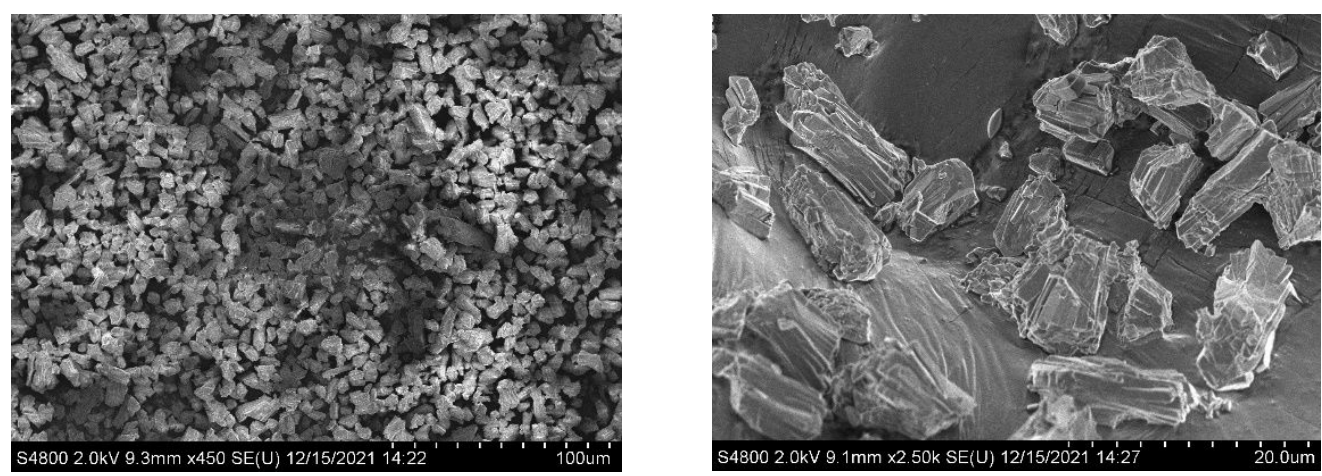

Figure S38. SEM images of thermal activated NU-913-HAc, showing the rod-shaped morphology.
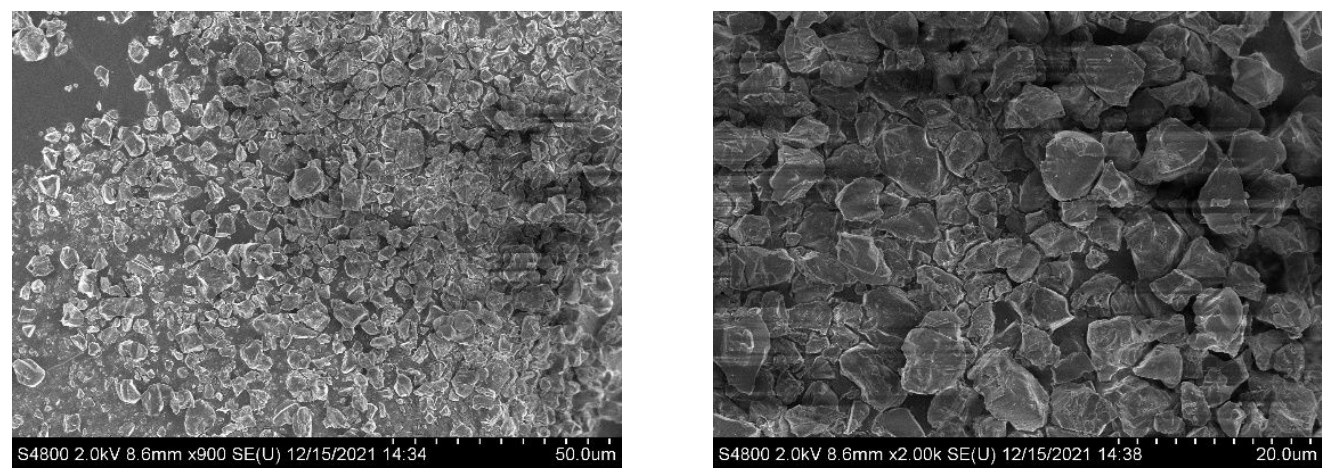

Figure S39. SEM images of thermal activated NU-913-TFA, showing the block-shaped morphology.

12. Table S3. Comparison of water sorption performances of NU-602, NU-913HAc, and NU-913-TFA and other porous materials

Table S3. Water uptake capacity at $\mathrm{P} / \mathrm{P}_{0}=0.6$ and 0.9 , and working capacity between $\mathrm{P} / \mathrm{P}_{0}=0.4$ and 0.6 . The data are all collected at $298 \mathrm{~K}$ except otherwise specified.

\begin{tabular}{|c|c|c|c|c|}
\hline Adsorbent & $\begin{array}{c}\text { Water } \\
\text { uptake } \\
\mathbf{( g / g )} \text { at } \\
\mathbf{P} / \mathbf{P}_{\mathbf{0}}=\mathbf{0 . 6}\end{array}$ & $\begin{array}{c}\text { Water } \\
\text { uptake } \mathbf{( g / g )} \\
\text { at } \mathbf{P} / \mathbf{P}_{\mathbf{0}}=\mathbf{0 . 9}\end{array}$ & $\begin{array}{c}\text { Water working } \\
\text { capacity } \mathbf{( g / g )} \\
\text { at } \mathbf{P} / \mathbf{P}_{\mathbf{0}} \text { between } \\
\mathbf{0 . 4} \text { and } \mathbf{0 . 6}\end{array}$ & Reference \\
\hline zeolite 13X & 0.32 & 0.33 & 0.02 & $\begin{array}{c}\text { J. Am. Chem. Soc. } \\
\mathbf{2 0 1 4}, 136,4369 .\end{array}$ \\
\hline MIP-200 & 0.43 & 0.45 & 0.02 & $\begin{array}{c}\text { Nat. Energy 2018, 3, } \\
985 .\end{array}$ \\
\hline
\end{tabular}




\begin{tabular}{|c|c|c|c|c|}
\hline MOF-801-P & 0.34 & 0.36 & 0.01 & $\begin{array}{l}\text { J. Am. Chem. Soc. } \\
\text { 2014, 136, } 4369 .\end{array}$ \\
\hline UiO-66 & 0.41 & 0.43 & 0.02 & $\begin{array}{c}\text { J. Am. Chem. Soc. } \\
\text { 2014, 136, } 4369 .\end{array}$ \\
\hline Y-shp-MOF-5 & 0.2 & 0.44 & 0.07 & $\begin{array}{l}\text { J. Am. Chem. Soc. } \\
\text { 2017, 139, } 10715 .\end{array}$ \\
\hline MOF-808 & 0.57 & 0.59 & 0.02 & $\begin{array}{l}\text { J. Am. Chem. Soc. } \\
\text { 2014, } 136,4369 .\end{array}$ \\
\hline PIZOF-2 & 0.01 & 0.68 & 0.01 & $\begin{array}{c}\text { J. Am. Chem. Soc. } \\
\text { 2014, 136, } 4369 .\end{array}$ \\
\hline MCM-41 & 0.18 & 0.77 & 0.01 & $\begin{array}{l}\text { J. Am. Chem. Soc. } \\
\text { 2014, 136, } 4369 .\end{array}$ \\
\hline NU-602 & 0.19 & 0.77 & - & This work \\
\hline NU-913-TFA & 0.74 & 0.85 & 0.64 & This work \\
\hline Ni-MOF-74-TPP & 0.71 & 0.88 & 0.13 & $\begin{array}{l}\text { J. Am. Chem. Soc. } \\
\text { 2017, 139, } 10601 .\end{array}$ \\
\hline MIL-101-Cr & 0.83 & 0.88 & 0.25 & $\begin{array}{c}\text { New J. Chem. 2014, } \\
38,3102 .\end{array}$ \\
\hline NU-913-HAc & 0.88 & 0.92 & 0.72 & This work \\
\hline $\mathrm{Co}_{2} \mathrm{Cl}_{2}$ (BTDD) & 0.94 & 0.96 & 0.03 & $\begin{array}{c}\text { ACS Cent. Sci. 2017, } 3 \text {, } \\
668 .\end{array}$ \\
\hline NU-1500-Cr & 1.02 & 1.09 & 0.84 & $\begin{array}{l}\text { J. Am. Chem. Soc. } \\
\text { 2019, 141, } 2900 .\end{array}$ \\
\hline Cr-soc-MOF-1 & 0.18 & 1.92 & - & Chem 2018, 4, 94. \\
\hline CAU-23 & $\sim 0.39$ & $\sim 0.41$ & - & $\begin{array}{c}\text { Nat. Commun. } 2019 \text {, } \\
10,3025\end{array}$ \\
\hline KMF-1 & $\sim 0.42$ & $\sim 0.45$ & - & $\begin{array}{c}\text { Nat. Commun. 2020, } \\
11,5112\end{array}$ \\
\hline MOF-303 & $\sim 0.42$ & $\sim 0.45$ & - & Science 2021, 374, 454 \\
\hline
\end{tabular}

